\title{
SOEP
}

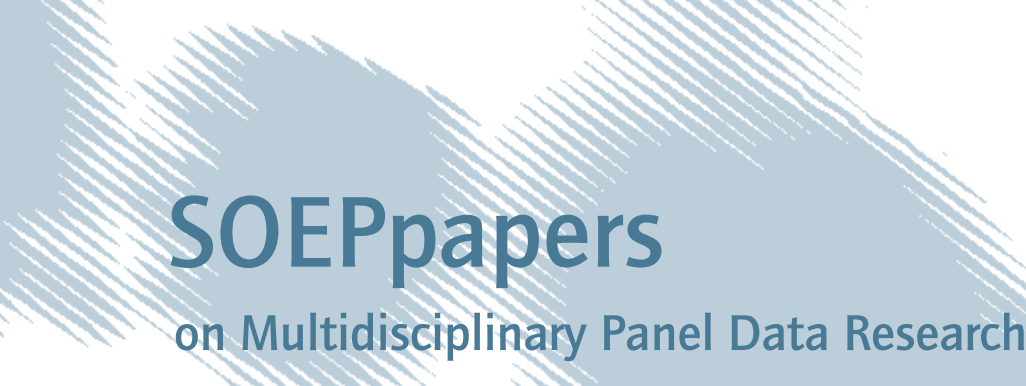

SOEPpapers
on Multidisciplinary Panel Data Research
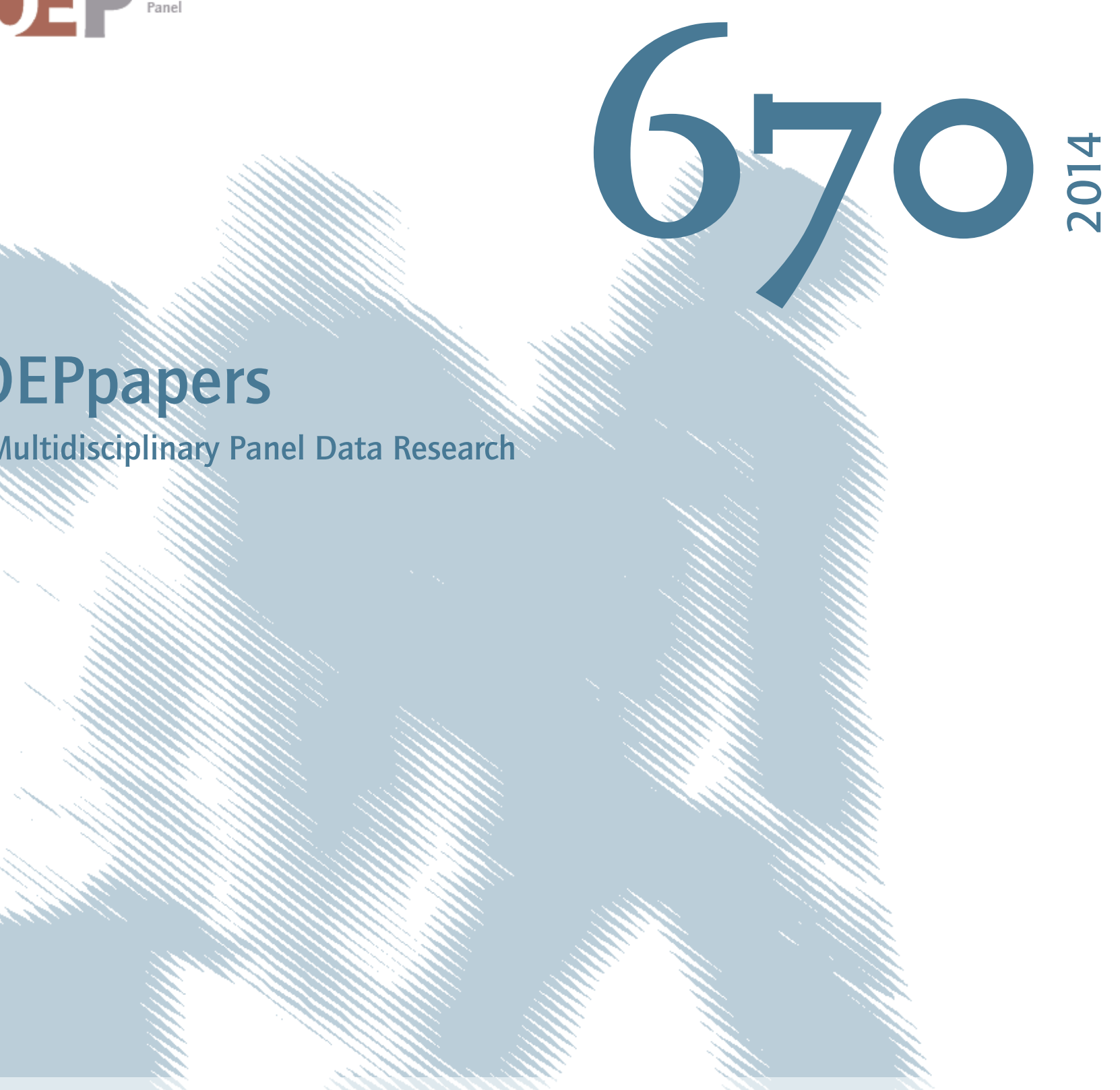

\section{Parental leave benefits and breastfeeding in Germany: Effects of the 2007 reform}




\section{SOEPpapers on Multidisciplinary Panel Data Research}

at DIW Berlin

This series presents research findings based either directly on data from the German SocioEconomic Panel Study (SOEP) or using SOEP data as part of an internationally comparable data set (e.g. CNEF, ECHP, LIS, LWS, CHER/PACO). SOEP is a truly multidisciplinary household panel study covering a wide range of social and behavioral sciences: economics, sociology, psychology, survey methodology, econometrics and applied statistics, educational science, political science, public health, behavioral genetics, demography, geography, and sport science.

The decision to publish a submission in SOEPpapers is made by a board of editors chosen by the DIW Berlin to represent the wide range of disciplines covered by SOEP. There is no external referee process and papers are either accepted or rejected without revision. Papers appear in this series as works in progress and may also appear elsewhere. They often represent preliminary studies and are circulated to encourage discussion. Citation of such a paper should account for its provisional character. A revised version may be requested from the author directly.

Any opinions expressed in this series are those of the author(s) and not those of DIW Berlin. Research disseminated by DIW Berlin may include views on public policy issues, but the institute itself takes no institutional policy positions.

The SOEPpapers are available at

http://www.diw.de/soeppapers

\section{Editors:}

Jürgen Schupp (Sociology)

Gert G. Wagner (Social Sciences, Vice Dean DIW Graduate Center)

Conchita D'Ambrosio (Public Economics)

Denis Gerstorf (Psychology, DIW Research Director)

Elke Holst (Gender Studies, DIW Research Director)

Frauke Kreuter (Survey Methodology, DIW Research Professor)

Martin Kroh (Political Science and Survey Methodology)

Frieder R. Lang (Psychology, DIW Research Professor)

Henning Lohmann (Sociology, DIW Research Professor)

Jörg-Peter Schräpler (Survey Methodology, DIW Research Professor)

Thomas Siedler (Empirical Economics)

C. Katharina Spieß (Empirical Economics and Educational Science)

ISSN: 1864-6689 (online)

German Socio-Economic Panel Study (SOEP)

DIW Berlin

Mohrenstrasse 58

10117 Berlin, Germany

Contact: Uta Rahmann | soeppapers@diw.de 


\title{
Parental leave benefits and breastfeeding in Germany
}

\section{Effects of the 2007 reform}

\author{
Anita Kottwitz* \\ Anja Oppermann ${ }^{\dagger}$ \\ C. Katharina Spieß $\beta^{\ddagger}$
}

Juni 2014

\begin{abstract}
While the health benefits of breastfeeding for both mothers and children are well known, breastfeeding may make it difficult for mothers to return early to the labor market. Maternity and parental leave regulations have been designed to reduce this conflict. In 2007, Germany put into effect a new parental leave benefit (Elterngeld). The related reform increased the number of parents eligible for benefits and changed the amount and duration of the benefits. The reform sought to decrease the pressure to return to the labor market soon after childbirth, especially for those parents who did not benefit under the old system. The current paper investigates whether this reform of parental leave impacted breastfeeding initiation and duration in Germany. We draw on representative survey data from the German Socio-Economic Panel Study (SOEP) from 2002 through 2012. Three breastfeeding measures are exploited 1) breastfeeding at birth or no breastfeeding initiation; 2) breastfeeding for at least four months; and 3) breastfeeding for at least six months.

We find no effect of the Elterngeld reform on breastfeeding initiation or breastfeeding for at least six months, but do find an effect on breastfeeding for at least four months. Applying a difference-in-difference approach, it is shown that mothers who were not affected by the reform did not change their breastfeeding behavior. Breastfeeding duration increased among mothers who benefited from the reform. The results were robust over various sensitivity tests including placebo regressions and controlling for regional indicators, among others. Thus, our empirical results provide evidence that the reform's goal of allowing parents to spend more time with their children during the first year of life also impacted breastfeeding behavior.
\end{abstract}

Keywords: Breastfeeding, Parental leave, Reform effects, Germany

${ }^{*}$ DIW Berlin, SOEP, Mohrenstraße 58, D-10117 Berlin, akottwitz@diw.de

${ }^{\dagger}$ University of Cologne, SOCLIFE, Richard-Strauss-Str. 2, D-50931 Cologne, oppermann@wiso.unikoeln.de

${ }^{\ddagger}$ DIW Berlin and Freie Universität Berlin, Mohrenstraße 58, D-10117 Berlin, kspiess@diw.de 
Acknowledgements: The authors are grateful to Silke Anger, Emilia del Bono, Christian Krekel, and Nicolas Ziebarth for their helpful comments. We also thank the "Babyfreundliches Krankenhaus" initiative for providing data on certified Baby-friendly hospitals in Germany. During the work on this working paper Anita Kottwitz was a pre-doctoral fellow of the International Max Planck Research School on the Life Course (LIFE, www.imprs-life.mpg.de; participating institutions: MPI for Human Development, Freie Universität Berlin, Humboldt-Universität zu Berlin, University of Michigan, University of Virginia, University of Zurich). 


\section{Introduction}

Increasing the prevalence and duration of breastfeeding has been identified as an important public health goal for a number of reasons (e.g., Rubin 2013): breastfeeding has been found to reduce the risk of infections and obesity in children and to improve their cognitive and emotional development (Belfield \& Kelly 2012; Anderson, Johnstone \& Remley 1999; Borra, Iacovou \& Sevilla 2012; Del Bono \& Rabe 2012; McCrory \& Layte 2012). ${ }^{1}$ On average, breastfeeding is related to more time spent in emotional care for the child than other forms of feeding (Smith \& Ellwood 2011). Breastfeeding is also associated with positive mental health effects and a reduced risk of breast cancer in mothers (Del Bono \& Rabe 2012, Beral et al. 2002). Breast milk is the recommended source of nutrition for newborn children for at least the first six months of life (World Health Organization and UNICEF 2003). However, breastfeeding may make it more difficult for mothers to return to the labor market soon after childbirth (e.g., Kobayashi \& Usui 2014; Roe et al. 1999; Berger, Hill \& Waldfogel 2005; Ogbuanu et al. 2011).

Maternity and parental leave provisions have been developed to mitigate this conflict. Some empirical studies show that the duration of maternity and parental leave is associated with improved child health and development (Ruhm 2000; Tanaka 2005; Waldfogel, Han \& Brooks-Gunn 2002; Carneiro, Loken \& Salvanes 2011), while others report no significant association (Rasmussen 2010; Liu \& Skans Oskar 2010; Dustmann \& Schönberg 2012) if parental leave extends beyond the first year of a child's life. It is assumed that the positive effects of parental leave provisions identified within the first year are partly a result of breastfeeding, yet only a few studies to date have focused directly on the relationship between breastfeeding and parental leave mandates. These include the studies by Baker \& Milligan (2008) and Huang \& Yang (2014), who estimate a positive impact of parental leave benefits on breastfeeding in Canada and California (USA).

\footnotetext{
${ }^{1} \mathrm{~A}$ recent sibling study finds no significant long-term breastfeeding benefits in sibling pairs in which one child was breastfed and the other was not (Colen \& Ramey 2014); however, this study does not account for e.g. exclusive breastfeeding duration.
} 
In this paper, we address the question of whether parental leave benefits have a direct effect on breastfeeding in Germany. In 2007, Germany passed a reform creating a new parental leave benefit (Elterngeld). The reform changed the amount of money provided to parents, the proportion of parents considered eligible, and the maximum benefit duration. As of 2007, all new parents became eligible to receive a parental leave benefit, in contrast to the previous parental leave system, which provided financial support only to selected parents. The 2007 reform replaced the previous means-tested child-rearing benefit (Erziehungsgeld) with a parental leave benefit (Elterngeld) of 67 percent of the pre-birth net income of the parent taking leave during the first year following childbirth (Spiess \& Wrohlich 2008). Most importantly, the new benefit offers much greater financial support to a much larger share of parents than the previous childrearing benefit, for which only parents with a low income were eligible. The reform therefore did not bring much change to these groups within the first year (for details, see Spiess \& Wrohlich 2008; Kluve \& Tamm 2013; Wrohlich et al. 2012a and Section 2.2). It aimed at reducing possible income losses due to childbirth and at facilitating family formation. It also sought to increase both parents' economic independence by reducing the maximum duration of transfers and thereby reducing career interruptions for women after the first year of their child's life. Additionally, the reform aimed at encouraging in particular fathers to take part in child care by introducing two additional "partner months." With the expansion of the benefit, the reform aimed at creating a protected phase (Schonraum) during the first year of a child's life, which has been shown to be particularly important for the interaction between parents and children and thus for child development in general (Deutscher Bundestag 2006; Bujard 2013). By lowering the pressure to return quickly to the labor market, the financial support allows parents to maintain a relatively constant standard of living-especially those who would not have benefited under the old system, i.e., mothers and fathers with incomes above the established threshold. Empirical research indicates that this major goal of the reform has been achieved: More parents (mostly mothers) now stay at home longer during the first year of their child's life (Spiess \& Wrohlich 2008; Kluve \& Tamm 2013; Wrohlich et al. 2012a). 
While rates of breastfeeding at birth have increased in the past decades and are relatively high overall in Germany (about 80 to 90 percent) compared to other countries, it is also reported that breastfeeding rates in Germany decline sharply in the first months after childbirth (Kersting \& Dulon 2002; Lange, Schenk \& Bergmann 2007; Dulon, Kersting \& Schach 2001).

With respect to maternal employment after birth, Germany shows relatively low employment rates for mothers with small children in comparison to other European countries (OECD 2014). In 2010, the employment rate of mothers with children less than a year old was almost 12 percent, while it increased to 40 percent once the child reached his or her first birthday.

Given these developments in maternal employment and a potential conflict between breastfeeding and employment, we address the following research question in more detail: Does the new parental leave reform impact breastfeeding initiation and duration in Germany? We use the reform as an exogenous policy variation to obtain causal evidence on breastfeeding behavior. We provide the first empirical evidence of this effect for Germany, a country with a much more generous family policy regime than the US or Canada, the countries that have been the focus of previous studies using comparable approaches (Baker \& Milligan 2008; Huang \& Yang 2014). As the German reform has not changed entitlement to parental leave with job protection for three years, we can isolate the effect of a change in size and duration of a benefit on breastfeeding from an effect of a longer leave period without benefits. This contributes to the existing knowledge, as this particular aspect has not been addressed in previous studies.

Our contribution is structured as follows: Section 2 gives an overview of previous findings on the conflict between maternal employment and breastfeeding as well as the impact of parental leave regulations. Next, the German context is presented, describing important details of the new parental leave reform and findings on the impact of the parental leave reform on maternal employment. Common findings on breastfeeding in Germany are discussed as well. Hypotheses are presented in Section 3. Data and estimation strategy are described in Section 4, followed by the main findings in Section 5. Additionally, several sensitivity checks for our findings are presented in Section 6. Finally, conclusions are presented in Section 7. 


\section{Background}

\subsection{Previous Findings}

A key strand of the literature for our research questions consists of studies on employment interruptions after childbirth and breastfeeding in general. There is strong empirical evidence that the duration of work leave and the duration of breastfeeding are closely related (Visness \& Kennedy 1997; Chatterji \& Frick 2005; Berger, Hill \& Waldfogel 2005; Ogbuanu et al. 2011; Kimbro 2006; Bick, MacArthur \& Lancashire 1998; Lindberg 1996). However, concerns have been raised about the causal direction of this relation; Roe et al. (1999) show, using a US sample, that the duration of maternity/parental leave affects the duration of breastfeeding, but not vice versa. Research also shows that working hours (part-time vs. full-time) and working conditions affect the duration of breastfeeding (Kurinij et al. 1989; Dennis 2002; Fein \& Roe 1998; Lindberg 1996). Lindberg (1996), for example, shows that mothers who return to the workforce full-time are more likely to quit breastfeeding than mothers who return to part-time employment.

Maternal employment can also impact whether a mother initiates breastfeeding at all. Empirically, an impact on initiation is only found either if the mother returns to the workforce very early after childbirth or intends to do so. "Early" refers here to a return to employment within six weeks (Noble \& Team 2001) or three months postpartum (Chatterji \& Frick 2005; Berger, Hill \& Waldfogel 2005; Guendelman et al. 2009). No effect of maternal employment on breastfeeding initiation is found if mothers return to work after a longer period of leave. Neither the intention to return to work within six months after childbirth (Noble \& Team 2001; Gielen et al. 1991) nor the intention and actual return to work within one year postpartum (Kimbro 2006; Visness \& Kennedy 1997) have been found to be correlated with breastfeeding initiation. However, most of the aforementioned studies do not explicitly focus on parental leave benefit regulations. Moreover, they are based mainly on US data and thus have to be interpreted in relation to their specific context: an institutional setting without generous leave regulations. 
Another strand of literature important for our study consists of studies analyzing the effects of parental leave and benefits policies on maternal employment decisions. They show that parental leave reforms extending the duration of parental leave mandates have a causal effect on individual employment interruptions. Although these studies focus on very different reforms, use different data sets and methods, their results are very similar: The longer the period of leave entitlement and the higher the benefits received, the longer the period of leave taken and the longer mothers wait to return to work. For such studies on Germany, see, for example, Ondrich et al. (2003), Schönberg \& Ludsteck (2007), Spiess \& Wrohlich (2008) Wrohlich et al. (2012a), and Kluve \& Schmitz (2014); for Austria see Lalive \& Zweimuller (2009); and for Canada see Baker \& Milligan (2010).

One of the few studies focusing directly on the effect of parental leave regulations and breastfeeding is Baker \& Milligan (2008), who examined how a Canadian parental leave reform affected postpartum employment and breastfeeding. The authors analyzed a reform that increased the share of women eligible for parental leave benefits as well as the length of leave from 25 to 50 weeks. They find an increase in the duration of parental leave taken by mothers as well as an increase in the share of mothers who breastfeed for at least six months. They find little impact of parental leave mandates on breastfeeding initiation. However, returning to employment was cited as a reason for quitting breastfeeding less often after the reform than before. Thus the reform shows an effect on the duration of breastfeeding, at least for those women whose behavior is responsive to maternity leave mandates. The findings of Baker \& Milligan (2008) imply an impact of parental leave entitlement and cash benefits on breastfeeding duration. As the reform under examination changed these two aspects, their specific impacts cannot be disentangled.

In a very recent study, Huang \& Yang 2014 also report a positive impact of parental leave benefits on breastfeeding in California (USA). The policy under examination introduced six weeks of paid maternity leave but without job protection. Like Baker \& Milligan, Huang \& Yang (2014) find no increase in breastfeeding initiation due to the reform. Even though Huang and Yang find a positive impact on breastfeeding duration, it has to be noted that the time span of financial support (six weeks) does not cover 
the duration of breastfeeding examined in this study (three, six, and nine months): The authors do not discuss the question of why six weeks of financial support should have an impact on the durations of breastfeeding they address. Additionally, they use a time span of 10 years between pre-reform measurement and the reform, which is a rather long period. The findings of Huang \& Yang (2014) imply that it is the cash benefits rather than job protection that positively impact breastfeeding duration. Because the duration of cash benefits does not cover the duration of breastfeeding examined in this study, however, this interpretation requires further evidence. Examining how a change in cash benefits that affects a family's financial situation in the first year of their child's life without changes in parental leave entitlement impacts breastfeeding is thus one of the major contributions of the present analysis.

\subsection{The German Parental Leave Reform and Breastfeeding}

\section{Parental Leave Reform of 2007}

On January 1, 2007, a new parental leave benefit was introduced in Germany (Elterngeld). The crucial points of this reform are that it changed, respective to the previously existing benefit, the terms of eligibility for parental leave benefits, thereby increasing the number of parents eligible, and it decreased the maximum duration of the benefit. Prior to 2007, a means-tested child-rearing benefit (Erziehungsgeld) was granted to parents based on overall household income. Couples were only eligible for the allowance if their yearly net income was below $€ 30,000$ ( $€ 23,000$ for single parents). About 76 percent of all parents were eligible for a child-rearing benefit (Kluve \& Tamm 2013, p. 989). Eligible parents received either $€ 300$ per month per child for a maximum of 24 months or $€ 450$ per month per child for a maximum of 12 months. ${ }^{2} 87$ percent of eligible parents received $€ 300$ and 13 percent received $€ 450$ for the first six months after childbirth (BMFSFJ 2008, p.32). After six months, the number of eligible parents decreased further: Relatively few parents received the benefit, since the household income threshold for eligibility was lowered to $€ 16,500$ per month $(€ 13,500$ for single

\footnotetext{
${ }^{2}$ Some federal states like Baden-Wurttemberg and Bavaria provided a benefit for additional 12 months prior to 2007.
} 
parents): at this stage, 66 percent of all previously eligible parents received $€ 300$ (or in a few cases $€ 450), 16$ percent received less than this amount, and for 18 percent stopped receiving the benefit (BMFSFJ 2008, p. 32).

The new benefit is available to all parents with a child born on or after January 1, 2007, and does not include income limits. The parent on leave receives 67 percent of her/his previous net income up to a maximum benefit of $€ 1,800$. The minimum of $€ 300$ per month is paid to parents without pre-birth income (Spiess \& Wrohlich 2008). ${ }^{3}$ The new parental leave benefit is granted for 12 months, with an additional two months if both parents take at least two months of parental leave. The parental leave benefit is intended to (partly) replace pre-birth earnings. A parent who takes parental leave and does not start working after childbirth receives the full amount (67 percent of her/his previous net income). In case of part-time work (up to 30 hours per week) the parent who takes parental leave is entitled to a benefit of 67 percent of the difference between pre- and post-birth income. Even though parental leave and benefit entitlements are gender-neutral, it is mothers rather than fathers who take (at least the majority of) parental leave and apply for benefits. Mothers who were employed prior to childbirth received on average $€ 863$ per month (Destatis 2011, p. 34), while non-employed mothers received on average $€ 330$ in 2010 . The vast majority of parents profit from the new parental leave benefit, meaning that they receive more financial support within the first year of their child's life now than they would have under the previous system (Wrohlich et al. 2012a).

While the amount of financial support provided to families changed dramatically with the reform, other important employment-related aspects did not change. Both before and after the reform, parents may work no more than 30 hours per week to receive financial support. The period of maternity protection is still eight weeks after the birth of a child, just as it was before the reform. During this time, mothers are not allowed to engage in paid employment. Employees receive a benefit based on their former average monthly income that has to be supplemented by the employer, which usually means

\footnotetext{
${ }^{3}$ It has to be noted that the replacement rate under the new parental leave benefit is between 67 percent and 100 percent for parents with a net income below $€ 1,000$ per month, i.e., the lower the income, the higher the replacement rate. (Spiess \& Wrohlich 2008).
} 
Table 1: Overview of German parental leave schemes before and after 2007

\begin{tabular}{|c|c|c|c|}
\hline & & $\begin{array}{l}\text { Old parental leave } \\
\text { scheme prior to } 2007\end{array}$ & $\begin{array}{l}\text { New parental leave } \\
\text { scheme since } 2007\end{array}$ \\
\hline \multirow[t]{3}{*}{ Financial support } & Amount & $\begin{array}{l}€ 300 \text {, means-tested bene- } \\
\text { fits (household income) }\end{array}$ & $\begin{array}{l}67 \% \text { of previous net labor } \\
\text { market income of the par- } \\
\text { ent on leave, minimum of } \\
€ 300 \text {, maximum of } € 1,800 \text {. }\end{array}$ \\
\hline & Duration & 24 months & $12+2$ months \\
\hline & Requirement & \multicolumn{2}{|c|}{ working less than 30 hours per week } \\
\hline \multirow[t]{3}{*}{ Statutory rules } & Maternity protection period & \multicolumn{2}{|c|}{$\begin{array}{l}\text { compulsory maternity protection period of } 8 \text { weeks } \\
\text { postpartum and income as during the } 3 \text { months be- } \\
\text { fore birth }\end{array}$} \\
\hline & Parental leave & \multicolumn{2}{|c|}{$\begin{array}{l}\text { entitlement to parental leave with guaranteed return } \\
\text { to previous job with the right to reduce hours to part- } \\
\text { time: } 36 \text { months }\end{array}$} \\
\hline & Breastfeeding legislation & \multicolumn{2}{|c|}{$\begin{array}{l}\text { Maternity protection law regulates rights to breast- } \\
\text { feeding breaks during working hours }\end{array}$} \\
\hline
\end{tabular}

Sources: Drasch 2013, Kluve \& Tamm 2013, Wrohlich et al. 2012a, Maternity Protection Act ("Mutterschutzgesetz" Article 3(2), Article 6(1), Article 7(1, 2, 3), Article 8(1))

that mothers do not see any decrease in their income ${ }^{4}$ (see Ondrich et al. 2003). After this two-month period, parents are entitled to take parental leave with a guaranteed return to their previous job until the child turns three. During these 36 months, parents also have the right to reduce their working hours to part-time. Table 1 summarizes the key aspects of these policy measures. As shown in Table 1, mothers are entitled to breastfeeding breaks during their working hours. Nevertheless there are numerous practical issues that still might make it difficult to balance work and breastfeeding. For example, to enable breastfeeding on demand, childcare would have to be provided in the mother's workplace. To the best of our knowledge, there is no study on the use of this entitlement in Germany.

An important goal of the 2007 reform was to lower the pressure on women to return to the workforce for financial reasons soon after childbirth. Empirically, this goal has been achieved. The parental leave reform decreased the differences in maternal employment during the first year of a child's life in Germany across all socio-economic groups. Since the reform, mothers are staying at home for a longer period of time in the first

\footnotetext{
${ }^{4}$ While employed mothers are entitled to Elterngeld after these eight weeks, others (e.g. mothers who are students or self-employed as well as fathers) are entitled from birth on.
} 
year of their child's life (Kluve \& Tamm 2013; Wrohlich et al. 2012a). The percentage of married mothers who entered part-time employment within the first year of their child's life decreased by more than 5 percent following the reform. The percentage of married mothers who entered full-time employment decreased by 14 percent (Wrohlich et al. 2012a, p. 42).

\section{Breastfeeding in Germany}

The official recommendation by the German National Breastfeeding Committee (Nationale Stillkommission) to new mothers in Germany is to exclusively breastfeed their child for at least four months (Bundesinstitut für Risikobewertung 2004). Introduction of solid food is recommended between four and six months of age. There is no recommended upper bound for the total duration of breastfeeding (Koletzko et al. 2013; Bundesinstitut für Risikobewertung 2004). In contrast, the World Health Organization recommends breastfeeding for at least six months (World Health Organization and UNICEF 2003).

In general, German breastfeeding behavior has not been studied in much detail, with the most recent results being from 2005 (Lange, Schenk \& Bergmann 2007). ${ }^{5}$ Nationwide data on breastfeeding in Germany are provided by the study "Stillen und Säuglingsernährung" (SuSe; see Dulon, Kersting \& Schach 2001) and the study "German Health Interview and Examination Survey for Children and Adolescents" (KiGGS; see Lange, Schenk \& Bergmann 2007). The few existing studies on breastfeeding in Germany indicate a high rate of breastfeeding initiation, but a sharp decline in the rate of breastfeeding in the first few months after the child is born. The data from the SuSe Study include prospective feeding information on 1,717 mother-infant pairs with children born between March and May 1997. 86 percent of the children were initially breastfed, but at four months only 59 percent received breast milk, falling to 48 percent at six months ${ }^{6}$ (Kersting \& Dulon 2002). The KiGGS Study provides the first repre-

\footnotetext{
${ }^{5}$ The more recent study by Kottwitz, Spiess \& Wagner (2011) provides new data on breastfeeding as well, but does not cover breastfeeding as a main focus.

${ }^{6}$ The figures refer to children who receive any breastfeeding, not necessarily exclusive breastfeeding. Exclusive breastfeeding refers to feeding with breast milk only, without "other liquids or solids
} 
sentative data on breastfeeding for Germany. About 17,000 children born between 1986 and 2005 and their parents participated. The questionnaire given to parents contained retrospective questions on breastfeeding. The data show that breastfeeding initiation and duration has increased over the 20 years of the survey (Lange, Schenk \& Bergmann 2007).

The empirical findings on breastfeeding in Germany are in line with those from other countries. A low socio-economic status of the mother (mostly operationalized by the educational level) is associated with lower probability of breastfeeding initiation as well as breastfeeding duration. A high socio-economic status, in contrast, is positively associated with breastfeeding initiation and duration (Lange, Schenk \& Bergmann 2007; Dulon, Kersting \& Schach 2001; Kohlhuber et al. 2008). Similar correlations have also been found in other studies all over the world (e.g., Dennis 2002 for an overview, USA: Fein \& Roe 1998; Chatterji \& Frick 2005; Heck et al. 2006; UK: Ogbuanu et al. 2011; Noble \& Team 2001; Sweden: Flacking, Dykes \& Ewald 2010; Italy: Bertini et al. 2003; Russia: Grjibovski et al. 2005; Iran: Hajian-Tilaki 2005). Maternal age is also often found to be associated with breastfeeding in Germany. Very young mothers are less likely to breastfeed and more likely to breastfeed for a shorter period of time (Lange, Schenk \& Bergmann 2007). Again, this is a global trend (e.g., Dulon, Kersting \& Schach 2001; Noble \& Team 2001; Ogbuanu et al. 2011; Grjibovski et al. 2005). Being a single parent negatively impacts breastfeeding initiation and duration (Dulon, Kersting \& Schach 2001; Ogbuanu et al. 2011; Grjibovski et al. 2005). Giving birth by Cesarean section reduces the probability of breastfeeding initiation in Germany (Kottwitz, Spiess \& Wagner 2011). This is in line with international findings; however, once breastfeeding is initiated, no differences in breastfeeding duration between Cesarean and non-Cesarean mothers can be observed (Prior et al. 2012; Hyde et al. 2012). Smoking is associated with a lower rate of breastfeeding initiation and shorter duration in Germany and other countries (Lange, Schenk \& Bergmann 2007; Kohlhuber et al. 2008; Bertini et al. 2003; Noble \& Team 2001; Chatterji \& Frick 2005; Ogbuanu et al. 2011).

(except vitamin/mineral drops, syrups)" (Kersting \& Dulon 2002), while any breastfeeding refers to feeding with breast milk regardless of additional feeding or not. 
Children that are born prematurely are less likely to be breastfed but, at the same time, are more likely to be breastfed at six months. Having an immigration background is associated with a higher rate of breastfeeding initiation, but this association is not affected by the amount of time the mother has lived in Germany. Furthermore, mothers from the eastern part of Germany are more likely to initiate breastfeeding but tend to breastfeed for a shorter period of time than mothers from western Germany (Lange, Schenk \& Bergmann 2007). Additionally, it is interesting to note that more East than West German mothers cite returning to work as the reason why they stopped breastfeeding (Dulon, Kersting \& Schach 2001).

\section{Hypotheses}

Time conflicts between breastfeeding and labor market participation are most likely to arise for mothers during the first year after childbirth. Therefore, our focus is on the changes in breastfeeding during the first year of a child's life since the 2007 parental leave reform. While we do not expect the 2007 reform to impact breastfeeding initiation, we expect a positive effect on breastfeeding duration (breastfeeding at four months and breastfeeding at six months). We have chosen four and six months because these are the recommended breastfeeding durations in Germany (see section 2.2.2).

As described above, the new parental leave reform seems to have reduced the differences of work leave across various socio-economic groups (Wrohlich et al. 2012a). In line with previous research (Gielen et al. 1991; Visness \& Kennedy 1997; Baker \& Milligan 2008; Kimbro 2006), we do not expect to find an increase in breastfeeding initiation rates due to the reform - mainly because the eight-week maternity protection period following childbirth did not change. During this period, mothers are not allowed to return to the labor market. Nevertheless, an increase in the rate of breastfeeding initiation in the first two months after childbirth might be related to other factors such as nationwide breastfeeding promotion campaigns or similar efforts. However, since 80 percent to 90 percent of all mothers in Germany already initiate breastfeeding (Kersting \& Dulon 2002; Lange, Schenk \& Bergmann 2007; Dulon, Kersting \& Schach 2001; Koletzko et al. 
2013), the effect of such campaigns may be expected to be rather small - apart from the important fact that no such broader campaign took place in our observation period.

Moreover, not all mothers were affected by the new reform (see 2.2.1). Thus we hypothesize that only mothers who are affected by the reform show a significant change in their breastfeeding behavior.

\section{Empirical Strategy and Data}

\subsection{Data}

Three binary outcome variables are of primary interest: 1) breastfeeding initiation at birth versus no breastfeeding initiation; 2) breastfeeding for at least four months versus less or none; and 3) breastfeeding for at least six months versus less or none. To investigate these outcomes, we made use of a representative German data set: the German Socio-Economic Panel Study (SOEP), waves 2002 through 2012. The SOEP, which started in 1984, is an annual, long-running household panel study with about 20,000 participants covering a broad range of socio-economic factors, demographic conditions, psychosocial factors, and health (Wagner, Frick \& Schupp 2007). Breastfeeding initiation and duration is assessed in the SOEP with an age-specific questionnaire for mothers of newborn children and a follow-up questionnaire for mothers of children aged two to three years (for the age-specific questionnaire, see Spiess 2011). The mothers were asked whether the child was breastfed and for how long (in months). The questionnaire does not ask whether the child was given any additional foods or nutritional supplements. Thus, our classification of breastfeeding comprises exclusive, predominant, and partial breastfeeding.

The SOEP started with these age-specific questionnaires in 2003, covering all birth cohorts starting with 2002; however, the breastfeeding questions were not part of these questionnaires from the very beginning. They were introduced in 2007 in the questionnaires for mothers of newborn children (birth cohorts 2006 and 2007) and children aged two to three years (birth cohorts 2004 and 2005). Thus, the SOEP provides breastfeeding information for children born from 2004 on. Breastfeeding status is derived from 
the questionnaires for mothers of children aged two to three years if breastfeeding information is either missing or censored in the newborn questionnaire; in all other cases, breastfeeding information is taken from the newborn questionnaire. Excluding observations with missing information on important control variables leaves us with a sample of 1,025 children at this stage. However, for several children, information is only available from a newborn questionnaire but not from the follow-up questionnaire distributed at the age of two to three years. 47 of those children were assessed very early, i.e., between birth and the age of six months. We therefore lack observation of the full potential breastfeeding period for some of these children. In order to avoid biased estimates due to the incorporation of partly incomplete breastfeeding histories, all 47 of these children were excluded. This left us with 978 children born to 802 mothers between 2004 and 2009 for the final analysis. ${ }^{7}$

For our analysis of the reform effect on breastfeeding, we controlled for other relevant factors affecting breastfeeding (see 2.2.2). All models include the following control variables: maternal education measured by highest degree obtained (least educated, vocationally educated, and tertiary educated mothers), poor physical health of the mother during the third trimester of pregnancy, poor mental health of the mother during the third trimester of pregnancy, first child, multiple birth, preterm birth, birth weight above 4,000 grams, maternal age at birth, planned pregnancy, family status, mother's residence in municipality with a population of less than 20,000 , residence in the western regions of Germany, and smoking status. Smoking information has been collected in the SOEP with every second wave since 2002. As smoking information is therefore missing in every other wave, smoking status was operationalized as "ever smoked," which identifies women who have stated at least once during survey participation that they are smokers. Maternal health factors and further individual characteristics were derived from the annual individual questionnaire from the survey year when the child was born. To account for the concern that breastfeeding would have increased even in the absence of a parental leave reform, a potential time trend was controlled for by including quarter-year dummy variable indicators.

\footnotetext{
${ }^{7}$ Dropping these 47 cases should not lead to a systematic bias as births are nearly randomly distributed over a calendar year. However, we performed an analysis for breastfeeding at birth versus no breastfeeding initiation for the full sample of 1,025 children, which yielded similar results.
} 
When estimating reform effects, we must rule out the possibility that another reform or intervention that may have led to a change in breastfeeding behavior took place at the same time as the parental leave reform. We are not aware of any such reform. However, one might argue that the increasing number of baby-friendly hospitals, an initiative by the World Health Organization and UNICEF (World Health Organization and UNICEF 2009), may have affected breastfeeding. ${ }^{8}$ Thus, data on certified babyfriendly hospitals were linked to the mother's residence by making use of geographic coordinates of the household and the relevant hospitals using "Geographic Information Systems" (GIS). ${ }^{9}$ By calculating simple Euclidean straight-line distance (McLafferty 2003) from the household to the nearest baby-friendly hospital, we identified whether the household is located within a distance of $20 \mathrm{~km}$ of a baby-friendly hospital or not. ${ }^{10}$ Additionally, we will also control for mode of delivery as previous research has found a great impact of Cesarean sections on breastfeeding initiation. However, information on mode of delivery is not available for the birth cohorts 2004 and 2005. Instead, we controlled for annual Cesarean section rates at the state level as an approximation (GBE 2012).

\subsection{Estimation Strategy}

The parental leave reform of 2007 creates an exogenous policy variation that can be used to compare breastfeeding before and after the reform. We first estimated a simple difference-in-difference (DiD) logistic regression for breastfeeding initiation and breastfeeding duration of the following notation:

\footnotetext{
${ }^{8}$ The number of certified baby-friendly hospitals in Germany rose from 19 to 51 out of more than 800 hospitals with a maternity unit in our observation period 2004 to 2009 (BFHI 2013).

${ }^{9}$ Data on certified baby-friendly hospitals of the years 2006 to 2009 was provided to the authors by the "Babyfreundliches Krankenhaus" (Baby-Friendly Hospital), an initiative supported by UNICED and the WHO (BFHI 2014). Hospital data from 2006 were also linked with data from the 2004 and 2005 birth cohorts. The sample size was reduced to $\mathrm{N}=963$ due to missing information on geographic coordinates of some households.

${ }^{10}$ The choice of a $20 \mathrm{~km}$ distance is justified by the fact that 98 percent of the German population can access a hospital within 20 minutes' travel time by car, i.e., a travel distance of $20 \mathrm{~km}$ at a speed of $60 \mathrm{~km} / \mathrm{h}$ (Beivers \& Spangenberg 2008). As geographic coordinates are not available for all households, a separate category for those missing cases was included in the estimation to avoid further dropping of observations.
} 


$$
\operatorname{Logit}\left(Y_{1 / 0}\right)=\ln \frac{P\left(Y_{i}=1\right)}{1-P\left(Y_{i}=1\right)}=\beta_{0}+\beta_{1} \text { reform } 2007+\ldots+\beta_{n} x_{n}+\epsilon
$$

where the outcome variable $Y_{i}$ stands for one of the three binary outcome variables on the child level: 1) breastfeeding at birth vs. no breastfeeding initiation; 2) breastfeeding for at least four months; and 3) breastfeeding for at least six months. The latter two outcome variables include women who did not start breastfeeding after childbirth to avoid selection bias due to a possibly nonrandom sample. reform 2007 is a dummy variable indicator equal to 1 if the child was born after the reform came into effect (birth cohorts 2007 to 2009).

Second, we applied a more specified difference-in-difference (DiD) approach that estimates the causal effect of the 2007 parental leave scheme. For this effect, two groups of mothers are of special interest: The first are mothers who were least affected and/or not affected by the new parental leave scheme (control group). The second are mothers who benefited from the reform and are now less inclined to return to the labor market quickly (treatment group). Given German parental leave regulations, the treatment and control groups are defined by their pre-pregnancy employment status and their annual household income (Table 2). The employment status and annual household income enable us to identify those women who were most likely to have benefited from the reform (treatment group) and those who were most likely to have received the same transfer amount in the first year after childbirth before and after the reform, thus being less likely to be affected by the reform (control group). We assume that non-working mothers with an annual household income of less than $€ 30,000$ were not affected by the new parental leave reform, and thus received the same monetary transfer amount of about $€ 300$ per month before and after the reform. ${ }^{11}$ Non-working mothers with an annual household income of more than $€ 30,000$ as well as working mothers, who earn their own income, should benefit from the new parental leave reform. Mothers

\footnotetext{
${ }^{11}$ As described above, after six months, only parents with a maximum household income of $€ 16,500$ (€13,500 for single parents) received a benefit of $€ 300$ or more per month prior to the reform. A separate robustness check was performed for breastfeeding at six months by allocating non-working mothers with an annual household income of more than $€ 16,500$ to the treatment group as they benefit from new parental leave reform after six months. This specification, however, does not change our main findings.
} 
Table 2: Definition of treatment and control groups

\begin{tabular}{|c|c|c|c|}
\hline Group & $\begin{array}{l}\text { Old parental leave } \\
\text { scheme } 2004 \text { to } 2006\end{array}$ & $\begin{array}{l}\text { New parental leave } \\
\text { scheme 2007-2009 }\end{array}$ & Operationalization \\
\hline $\begin{array}{l}\text { Treatment } \\
\text { Group }\end{array}$ & $\begin{array}{l}\text { No benefit or benefit below } \\
€ 300 / \text { month }\end{array}$ & $\begin{array}{l}\text { Eligible for } € 300 \text { to } \\
€ 1,800 / \text { month }\end{array}$ & $\begin{array}{l}\text { mothers with pre-birth employment or } \\
\text { without pre-birth employment and an- } \\
\text { nual household income greater than } \\
€ 30,000\end{array}$ \\
\hline Control Group & Eligible for $€ 300 /$ month & Eligible for $€ 300 /$ month & $\begin{array}{l}\text { mothers without pre-birth employ- } \\
\text { ment and annual household income less } \\
\text { than } € 30,000\end{array}$ \\
\hline
\end{tabular}

Note: Treatment and control groups are defined by the expected monthly parental leave benefit in the first six months after childbirth.

with a high household income would not have received any transfers before the reform. Empirical studies show that employed mothers benefit most from the new parental leave benefit (Wrohlich et al. 2012b). In our sample, we derived the employment status from the monthly biography calendar ten months before childbirth. We differentiated between working (full-time, part-time) and not working (housewife, unemployed, in education). ${ }^{12}$ Pre-pregnancy employment status was chosen to avoid any misreporting due to pregnancy-related (sick) leave.

In the absence of a reform effect, treatment and control groups would follow the same distribution patterns and a parallel breastfeeding trend over time (common linear trend assumption). The DiD of the following notation estimates the causal reform effects on breastfeeding initiation and duration:

$$
\begin{array}{r}
\operatorname{Logit}\left(Y_{1 / 0}\right)=\ln \frac{P\left(Y_{i}=1\right)}{1-P\left(Y_{i}=1\right)}=\beta_{0}+\beta_{1} \text { reform } 2007+\beta_{2} \text { treat }+ \\
\beta_{3} \text { reform } 2007 \times \text { treat }+\ldots+\beta_{n} x_{n}+\epsilon
\end{array}
$$

where treat measures treatment status and is equal to one for all mothers that were affected by the reform. Re form $2007 \times$ treat is the interaction effect of re form 2007 and

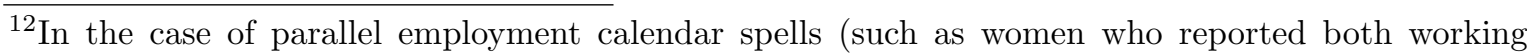
part-time and being a homemaker), employment is given priority when coding employment status before pregnancy. The category "in education" comprises all women who stated that they were in the vocational or tertiary educational system.
} 
treat and identifies the causal effect of the reform on breastfeeding initiation respectively the other breastfeeding "outcomes". The sign of the coefficient of the interaction term is the same as the sign of the treatment effect (Puhani 2012); hence, a positive coefficient would yield a positive reform effect on breastfeeding. Furthermore, the interaction effect was conceptualized in terms of predicted probabilities to ease interpretation.

$$
P\left(Y_{i}=1\right)=\frac{e^{\beta_{0}+\beta_{1} \text { reform } 2007+\beta_{2} \text { treat }+\beta_{3} \text { reform } 2007 \times \text { treat }+\ldots+\beta_{n} x_{n}+\epsilon}}{1+e^{\beta_{0}+\beta_{1} \text { reform } 2007+\beta_{2} \text { treat }+\beta_{3} \text { reform } 2007 \times \text { treat }+\ldots+\beta_{n} x_{n}+\epsilon}}
$$

As predicted probabilities are sensitive to the choice of variable values, and as holding covariates fixed at their mean values may not represent a mother in reality, predicted probabilities were calculated for an average mother (mother's age at birth: 30, good physical health during first 3 months after childbirth, birth at term, first child) living in the Eastern states of Germany. In alternative specifications, sensitivity analyses are performed by holding covariates constant at other plausible values.

A major concern in DiD estimates is the potential endogeneity of a reform itself. The estimated reform effect is biased if, for example, the reform led to a change in individual fertility choices-for instance, if some women who would have otherwise remained childless based their decisions to have children on the new parental leave regulation. Recent evidence on the short-term consequences of the parental leave reform in 2007 shows that mothers aged 34 and younger have a lower probability of a higher-order birth (Bujard \& Passet 2013). However, the authors do not identify a causal effect (ibid.). Thyrian et al. (2010) find increased higher-order fertility among certain subgroups, such as mothers with a higher socio-economic status, after the reform. However, the data from this study are not representative for Germany. Moreover, the question is whether we see such differences in our sample. Table 3 reports the summary statistics of individual characteristics of our sample before and after the reform. The results indicate that covariates between both sample groups remained similar and are not statistically different, except for first-time pregnancies, which are significantly less frequent after the reform and Cesarean section rates, which increased significantly over time. In addition, Table 4 shows that covariate distribution of treatment and control groups is very 


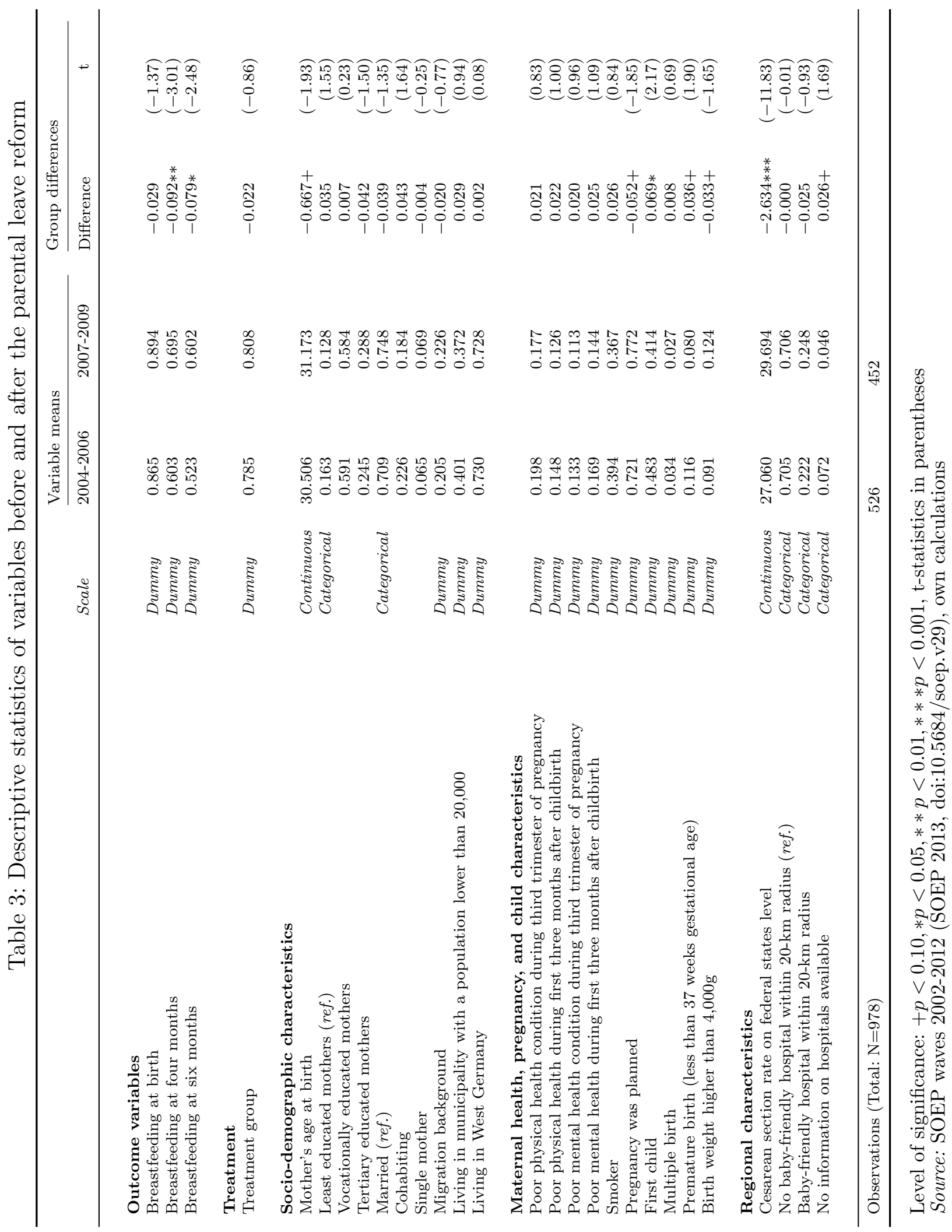


Figure 1: Breastfeeding rates in Germany before and after 2007

Breastfeeding Rates
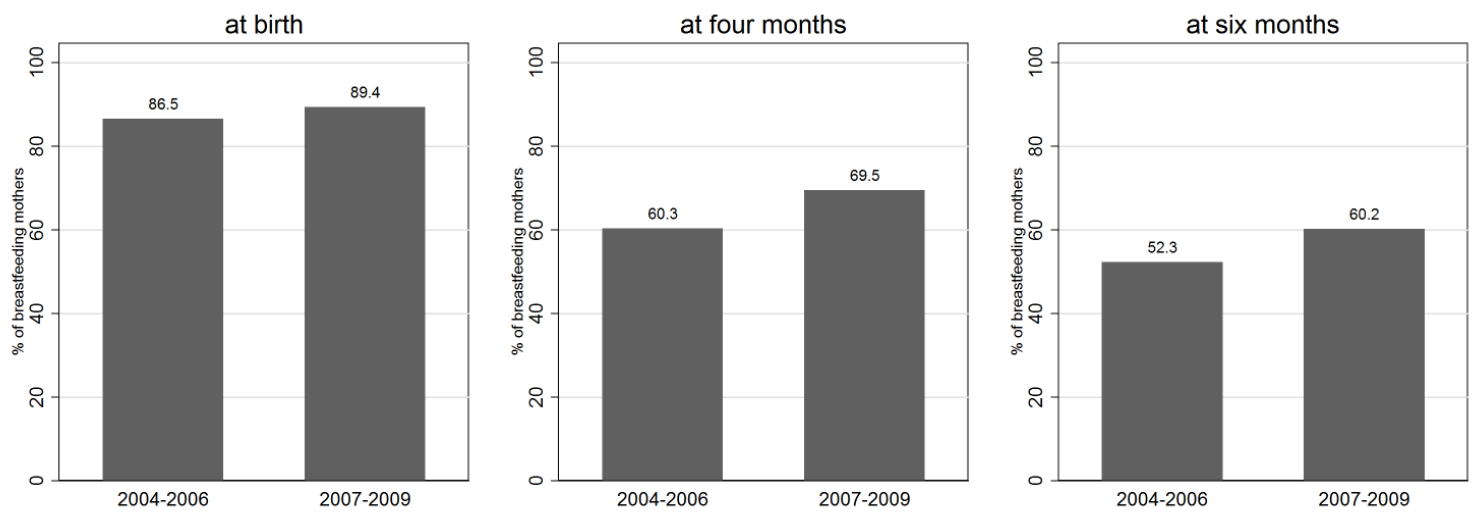

Source: SOEP waves 2002-2012 (SOEP 2013, doi:10.5684/soep.v29), own calculations

similar before and after the reform. Thus, we have no reason to assume that mothers in our sample who gave birth after the reform are different from mothers who gave birth prior to the reform.

Multiple pregnancies by the same mother are adjusted by estimating the robust variance in the logistic regression that adjusts for within-cluster correlation (Rogers 1993).

\section{Results}

Figure 1 shows unadjusted breastfeeding rates of mothers before and after the reform. In line with our expectations, we find no statistically significant difference between breastfeeding initiation before and after the parental leave reform in 2007 (see also Table 3). However, we do find a significant increase in breastfeeding duration: breastfeeding at four months increased by 9.2 percentage points and breastfeeding at six months by 7.9 percentage points.

Adjusting for socio-demographic characteristics as well as further maternal and childrelated characteristics in a logistic regression of the equation 3 , a positive reform effect can still be observed for breastfeeding at four months (t-value=1.94) and for breastfeeding at six months $(\mathrm{t}$-value $=2.05$, see Table 5$)$. 


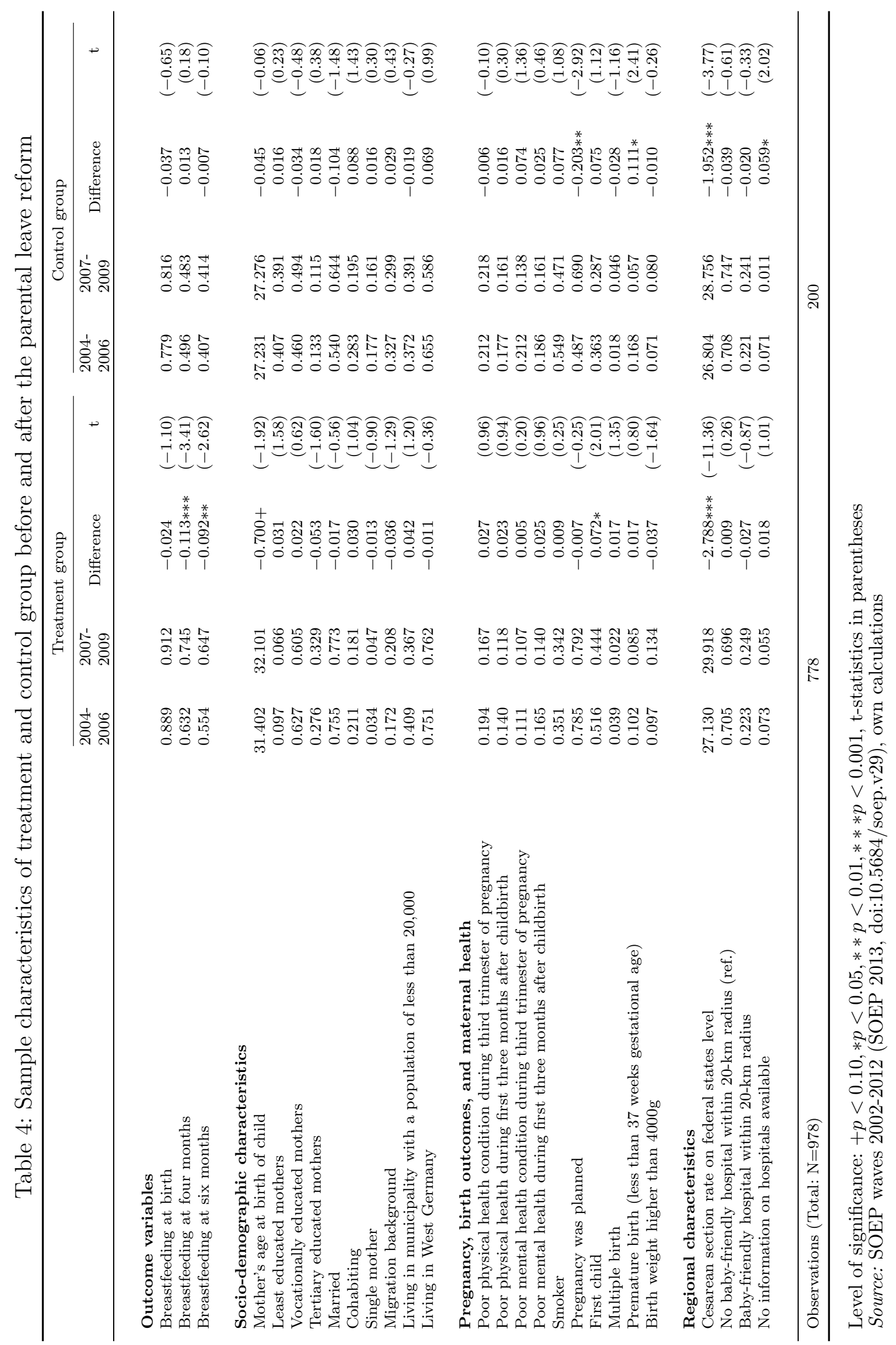


Table 5: The effect of parental leave on breastfeeding initiation and duration (logistic regression)

\begin{tabular}{lccc}
\hline & Breastfeeding at birth & $\begin{array}{c}\text { Breastfeeding at four } \\
\text { months }\end{array}$ & $\begin{array}{c}\text { Breastfeeding at six } \\
\text { months }\end{array}$ \\
& $(1)$ & $(2)$ & $(3)$ \\
Reform & -0.101 & $0.480+$ & $0.476^{*}$ \\
& $(-0.28)$ & $(1.94)$ & $(2.05)$ \\
\hline & & & 978 \\
$\mathrm{~N}$ (children) & 978 & 802 & 802 \\
$\mathrm{~N}$ (cluster mothers) & 802 & 0.140 & 0.130 \\
Pseudo- $R^{2}$ & 0.188 & $71.17 \%$ & $67.38 \%$ \\
\hline Correctly classified & $88.86 \%$ & $C h i^{2}$ & $C h i^{2}$ \\
& $C h i^{2}$ & {$[\mathrm{p}]$} & 130.222 \\
& {$[\mathrm{p}]$} & 146.732 & {$[0.000]$} \\
Wald test & 128.913 & {$[0.000]$} & 5.456 \\
Goodness-of-fit test & {$[0.000]$} & 3.621 & {$[0.708]$} \\
(grouped into deciles of risk, Hosmer \& & 5.988 & $[0.89])$ & \\
Lemeshow) & {$[0.649]$} & & \\
\hline
\end{tabular}

Level of significance: $+p<0.10, * p<0.05, * * p<0.01, * * * p<0.001$, t-statistics in parentheses Note: All models control for covariates listed in Table 3 plus quarter-year dummy variables. The cutoff point is set at 0.5 for the calculation of the classification statistics.

Source: SOEP waves 2002-2012 (SOEP 2013, doi:10.5684/soep.v29), own calculations

However, a reform effect should only be observed among those women who actually benefited from the reform (treatment group). Figure 2 shows the unadjusted breastfeeding rates before and after the reform for the control and treatment group. Breastfeeding initiation did not change significantly in either the control or the treatment group. Breastfeeding duration did significantly increase among mothers in the treatment group but not in the control group. Breastfeeding at four months has increased by 11.3 percentage points and breastfeeding at six months by 9.2 percentage points among mothers in the treatment group (see also Table 4).

Results from the DiD logistic regression models of the equation (2) controlling for maternal and child-related characteristics are presented in Table 6a. In line with the descriptive findings, we find no effect of the parental leave reform on breastfeeding initiation; but there is an effect on breastfeeding at four months. We find no statistically significant effect of the reform on breastfeeding of at least six months.

Further results from our main DiD regression model are presented in Table 6b. In a first step, predicted probabilities are calculated for different combinations of the interaction 
Table 6: DiD estimates on breastfeeding initiation and duration (logistic regression)

(a) Log odds

\begin{tabular}{lccc}
\hline & Breastfeeding at birth & $\begin{array}{c}\text { Breastfeeding at four } \\
\text { months }\end{array}$ & $\begin{array}{c}\text { Breastfeeding at six } \\
\text { months }\end{array}$ \\
& $(1)$ & $(2)$ & $(3)$ \\
Reform & -0.204 & -0.114 & 0.054 \\
& $(-0.37)$ & $(-0.29)$ & $(0.14)$ \\
Treatment & 0.527 & 0.042 & 0.076 \\
& $(1.45)$ & $(0.15)$ & $(0.28)$ \\
Reform x Treatment & 0.119 & $0.760^{*}$ & 0.524 \\
& $(0.23)$ & $(2.02)$ & $(1.41)$ \\
\hline N(children) & & & 978 \\
N(cluster mothers) & 978 & 802 & 802 \\
Pseudo- $R^{2}$ & 802 & 0.146 & 0.133 \\
\hline Correctly classified & 0.194 & $72.09 \%$ & $67.08 \%$ \\
\hline & $88.55 \%$ & $C h i^{2}$ & $C h i^{2}$ \\
& $C h i^{2}$ & {$[\mathrm{p}]$} & 130.256 \\
& {$[\mathrm{p}]$} & 146.734 & {$[0.000]$} \\
Wald test & & {$[0.000]$} & 10.310 \\
Goodness-of-fit test & {$[37.964$} & {$[0.564$} & {$[0.244]$} \\
(grouped into deciles of risk, Hosmer \& & {$[0.000]$} & & \\
\hline
\end{tabular}

(b) Predicted Probabilities of DiD estimates

$\begin{array}{ccc}\text { Breastfeeding at birth } & \begin{array}{c}\text { Breastfeeding at four } \\ \text { months }\end{array} & \begin{array}{c}\text { Breastfeeding at six } \\ \text { months }\end{array}\end{array}$

$(2)$

(3)

Interaction: Reform $\times$ Treatment

Before\#Control

Before\#Treatment

After\#Control

After\#Treatment

Control: Diff. After - Before

Treatment: Diff. After - Before

DiD

$\mathrm{N}$

$\begin{array}{cc}0.926^{* * *} & 0.556^{* * *} \\ (19.51) & (5.17) \\ 0.953^{* * *} & 0.564^{* * *} \\ (33.02) & (5.99) \\ 0.912^{* * *} & 0.532^{* * *} \\ (21.94) & (6.75) \\ 0.949^{* * *} & 0.693^{* * *} \\ (38.49) & (11.21) \\ & \\ -0.014 & -0.024 \\ (-0.39) & (-0.29) \\ -0.004 & 0.129^{*} \\ (-0.23) & (2.37) \\ & \\ \mathbf{0 . 0 1 0} & \mathbf{0 . 1 5 3 *} \\ \mathbf{( 0 . 3 0 )} & \mathbf{( 1 . 9 7 )}\end{array}$

978

$$
\begin{gathered}
(4.19) \\
0.435^{* * *} \\
(4.94) \\
0.430^{* * *} \\
(5.60) \\
0.557^{* * *} \\
(8.37) \\
\\
0.011 \\
(0.14) \\
0.122^{*} \\
(2.52) \\
\\
\mathbf{0 . 1 1 1} \\
\mathbf{( 1 . 4 4 )}
\end{gathered}
$$$$
0.419^{* * *}
$$

978

Level of significance: $+p<0.10, * p<0.05, * * p<0.01, * * * p<0.001$, t-statistics in parentheses Note: All models control for covariates listed in Table 3 plus quarter-year dummy variables. The cutoff point is set at 0.5 for the calculation of the classification statistics. Predicted probabilities base on the logistic regression model (Table 6a) by holding covariates fixed at following values: East German mothers, mother's age at birth of child: 30, good physical health during first three months after childbirth, birth at term, first child (main specification).

Source: SOEP waves 2002-2012 (SOEP 2013, doi:10.5684/soep.v29), own calculations 
Figure 2: Breastfeeding rates in Germany by treatment and control groups

\section{Breastfeeding Rates}
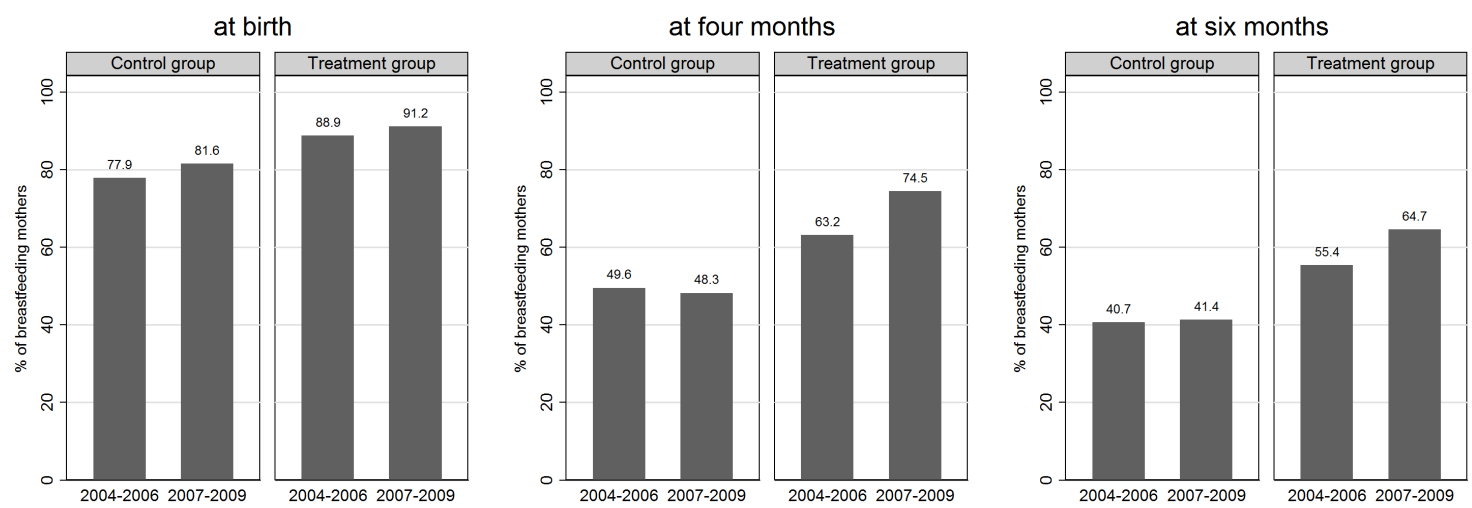

Source: SOEP waves 2002-2012 (SOEP 2013, doi:10.5684/soep.v29), own calculations

effect: control group before the reform (Before\#Control), treatment group before the reform (Before\#Treat), control group after the reform (After\#Control), and treatment group after the reform (After\#Treat) as shown in the upper part of Table 6b. In a second step, we tested whether there are differences in breastfeeding probabilities of our groups of interest, namely 1) the treatment group and 2) the control group, both before and after the 2007 reform. Differences are calculated by subtracting pre-reform estimates from post-reform estimates (as shown in the lower part of Table 6b). There is a significant difference in the treatment group before and after the reform with regard to breastfeeding at four months. Mothers who were affected by the parental leave reform (treatment group) show a higher probability (0.693) of breastfeeding for at least four months after than before the reform (0.564), which is nearly 13 percentage points lower. No effect can be found for mothers in the control group when comparing estimates before and after the reform, for which we calculated a difference of -2 percentage points. The DiD shows a significant difference in probabilities of 15 percentage points indicating a causal reform effect on breastfeeding of at least four months. No significant DiD can be found for breastfeeding at six months. These results therefore partly confirm our hypothesis that the parental leave reform affected breastfeeding duration. 


\section{Sensitivity Analyses}

In order to confirm our findings, we applied several sensitivity analyses. Furthermore, we tested whether our results are sensitive to the choice of covariates when estimating the predicted probabilities by holding covariates constant at other plausible values (Table A1 in the appendix). The 2007 parental leave reform shows an effect on the treatment group but not on the control group in all model specifications for East German mothers. Again, significant reform effects can be found for breastfeeding at four months but not for breastfeeding initiation and for breastfeeding at six months. Interestingly, the reform effect seems weaker for West German mothers and is found to be significant at the 10 percent level.

Next we address the issue of our relatively large observation window of three years before and after the reform. As treatment groups are mainly operationalized by prepregnancy employment status, treatment status is prone to endogeneity either if women adapt their employment behavior due to the reform or if childbearing is reduced or increased dependent on women's employment status. For example, if non-employed potential mothers have been "adjusting" their fertility since the 2007 reform by taking a job just before becoming pregnant to be eligible for parental benefits, the reform itself cannot be interpreted as having a causal effect on breastfeeding. To account for this concern, the analysis is restricted to birth cohorts 2006 and 2007 to compare breastfeeding in a smaller time frame around the point of time when the reform came into effect. This enables us to draw conclusions from a comparison sample which has been largely unanticipated by the reform: The public debate about the new German parental leave benefit scheme started in May 2006 (Kluve \& Tamm 2013), passed the parliament on September 29, 2006, and was approved by the Federal Assembly on November 3, 2006. Theoretically, women could have started family planning in anticipation of the new reform in May 2006 at the earliest (see also Kluve \& Schmitz 2014). However, as the parental leave benefit is calculated from the annual income before childbirth, only mothers who worked a longer period of time would have had a potential incentive to plan to have a child because of the benefit increase. However, conception may take some time. Furthermore, it is possible that potential mothers 
Table 7: DiD estimates on breastfeeding initiation and duration, birth cohorts 2006 and 2007: Logistic regression

\begin{tabular}{|c|c|c|c|}
\hline & $\begin{array}{c}\text { Breastfeeding at birth } \\
\text { (1) }\end{array}$ & $\begin{array}{l}\text { Breastfeeding at four } \\
\text { months } \\
(2)\end{array}$ & $\begin{array}{c}\text { Breastfeeding at six } \\
\text { months } \\
(3)\end{array}$ \\
\hline Reform & $\begin{array}{l}3.062 \\
(1.03)\end{array}$ & $\begin{array}{l}-0.414 \\
(-0.50)\end{array}$ & $\begin{array}{l}-0.241 \\
(-0.31)\end{array}$ \\
\hline Treatment & $\begin{array}{l}0.965 \\
(1.51)\end{array}$ & $\begin{array}{l}0.057 \\
(0.13)\end{array}$ & $\begin{array}{l}0.175 \\
(0.42)\end{array}$ \\
\hline Reform x Treatment & $\begin{array}{l}1.564 \\
(1.37)\end{array}$ & $\begin{array}{l}1.442^{*} \\
(2.19)\end{array}$ & $\begin{array}{c}1.196+ \\
(1.91)\end{array}$ \\
\hline $\begin{array}{l}\mathrm{N} \text { (children) } \\
\mathrm{N} \text { (cluster mothers) } \\
\text { Pseudo- } R^{2}\end{array}$ & $\begin{array}{c}319 \\
311.000 \\
0.401\end{array}$ & $\begin{array}{c}319 \\
311.000 \\
0.176\end{array}$ & $\begin{array}{c}319 \\
311.000 \\
0.143\end{array}$ \\
\hline \multirow[t]{2}{*}{ Correctly classified } & $90.91 \%$ & $69.28 \%$ & $68.65 \%$ \\
\hline & $\begin{array}{l}\text { Chi2 } \\
{[\mathrm{p}]}\end{array}$ & $\begin{array}{c}\mathrm{Chi} 2 \\
{[\mathrm{p}]}\end{array}$ & $\begin{array}{c}\mathrm{Chi} 2 \\
{[\mathrm{p}]}\end{array}$ \\
\hline A & $\begin{array}{l}135.353 \\
{[0.000]}\end{array}$ & $\begin{array}{l}145.786 \\
{[0.000]}\end{array}$ & $\begin{array}{l}132.598 \\
{[0.000]}\end{array}$ \\
\hline $\begin{array}{l}\text { Goodness-of-fit test (grouped into } \\
\text { deciles of risk, Hosmer \& Lemeshow) }\end{array}$ & $\begin{array}{l}5.637 \\
{[0.688]}\end{array}$ & $\begin{array}{c}7.975 \\
{[0.434]}\end{array}$ & $\begin{array}{l}8.420 \\
{[0.394]}\end{array}$ \\
\hline
\end{tabular}

Level of significance: $+p<0.10, * p<0.05, * * p<0.01, * * * p<0.001$, t-statistics in parentheses Note: All models control for covariates listed in Table 3 plus quarter-year dummy variables. The cutoff point is set at 0.5 for the calculation of the classification statistics.

Source: SOEP waves 2002-2012 (SOEP 2013, doi:10.5684/soep.v29), own calculations

enter the labor market to increase their income before childbirth. We argue that it is unlikely that non-working women would be able to find a job at such short notice and immediately begin earning a high salary. Therefore, it seems reasonable to assume that the pre-birth employment statuses of women with children born in 2007 were largely unaffected by the reform. DiD estimations in Table 7 show similar results with the shorter observation period as in the main specification with higher breastfeeding probabilities at four months after the reform.

Furthermore, we examined the plausibility of the DiD estimator by applying so-called placebo regressions that shift the time cut to a year before the reform (i.e., placebo reform in 2006) to explore whether there are any preexisting breastfeeding trends. This fictitious reform should not show any statistical significant effect. If it does, this would be an indicator that treatment and control groups follow a parallel breastfeeding trend 
Table 8: DiD estimates on breastfeeding initiation and duration: Placebo estimates

\begin{tabular}{lccc}
\hline & Breastfeeding at birth & $\begin{array}{c}\text { Breastfeeding at four } \\
\text { months }\end{array}$ & $\begin{array}{c}\text { Breastfeeding at six } \\
\text { months }\end{array}$ \\
& $(1)$ & $(2)$ & $(3)$ \\
Placebo reform 2006 & 0.311 & -0.003 & 0.181 \\
& $(0.57)$ & $(-0.01)$ & $(0.45)$ \\
Treatment & 0.665 & 0.124 & 0.087 \\
& $(1.42)$ & $(0.35)$ & $(0.26)$ \\
Placebo reform 2006 x Treatment & -0.140 & 0.414 & 0.380 \\
& $(-0.25)$ & $(1.05)$ & $(0.98)$ \\
N(children) & 978 & 978 & 978 \\
N(cluster mothers) & 802 & 802 & 802 \\
Pseudo- $R^{2}$ & 0.194 & 0.142 & 0.132 \\
\hline
\end{tabular}

Level of significance: $+p<0.10, * p<0.05, * * p<0.01, * * * p<0.001$, t-statistics in parentheses Note: All models control for covariates listed in Table 3 plus quarter-year dummy variables.

Source: SOEP waves 2002-2012 (SOEP 2013, doi:10.5684/soep.v29), own calculations

over the time and that they are both independent from the new parental leave reform. In Table 8, we show regressions with a fictitious reform set at 2006 to check whether there are any existing breastfeeding trends before the reform in 2007 that might have an effect on our findings. No such effects were found in these specifications, indicating that our estimated effects of the reform in 2007 are plausible and that a causal reform effect is identified.

We performed several further robustness checks (Table 9). Firstly, we controlled for the availability of publicly funded day care centers for children under the age of three. ${ }^{13}$ If a mother lives in a region with no access to publicly funded day care centers, she might not be able to return to work-even if she wants to-and consequently may continue breastfeeding. Hence, we link our data to information on the availability of day care slots for children under 3 in the county where the mother lives (data on day care slots for children under the age of one are not available on the county level). The information on the availability of day care centers is provided by the Federal Statistical Office (Statistisches Bundesamt 2013a). However, controlling for this availability does

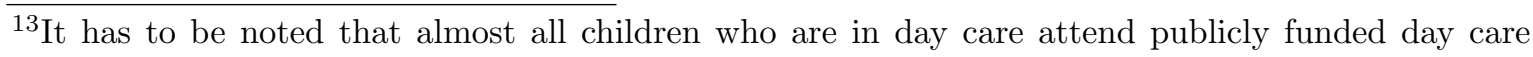
centers.
} 
Table 9: Robustness checks: DiD estimates on breastfeeding initiation and duration

\begin{tabular}{|c|c|c|c|c|c|c|c|c|c|}
\hline & \multicolumn{3}{|c|}{ Breastfeeding at birth } & \multicolumn{3}{|c|}{$\begin{array}{l}\text { Breastfeeding at four } \\
\text { months }\end{array}$} & \multicolumn{3}{|c|}{$\begin{array}{l}\text { Breastfeeding at six } \\
\text { months }\end{array}$} \\
\hline & (1a) & $(1 b)$ & $(1 \mathrm{c})$ & $(2 \mathrm{a})$ & $(2 \mathrm{~b})$ & $(2 \mathrm{c})$ & $(3 a)$ & $(3 b)$ & $(3 \mathrm{c})$ \\
\hline Reform & $\begin{array}{l}-0.209 \\
(-0.35)\end{array}$ & $\begin{array}{l}-0.196 \\
(-0.35)\end{array}$ & $\begin{array}{l}-0.199 \\
(-0.36)\end{array}$ & $\begin{array}{l}-0.143 \\
(-0.35)\end{array}$ & $\begin{array}{l}-0.114 \\
(-0.29)\end{array}$ & $\begin{array}{l}-0.165 \\
(-0.42)\end{array}$ & $\begin{array}{l}0.092 \\
(0.23)\end{array}$ & $\begin{array}{l}0.050 \\
(0.13)\end{array}$ & $\begin{array}{l}0.012 \\
(0.03)\end{array}$ \\
\hline Treatment & $\begin{array}{c}0.625+ \\
(1.70)\end{array}$ & $\begin{array}{l}0.504 \\
(1.38)\end{array}$ & $\begin{array}{l}0.528 \\
(1.45)\end{array}$ & $\begin{array}{l}0.074 \\
(0.26)\end{array}$ & $\begin{array}{l}0.022 \\
(0.08)\end{array}$ & $\begin{array}{l}0.067 \\
(0.24)\end{array}$ & $\begin{array}{l}0.105 \\
(0.38)\end{array}$ & $\begin{array}{l}0.047 \\
(0.17)\end{array}$ & $\begin{array}{l}0.137 \\
(0.50)\end{array}$ \\
\hline Reform x Treatment & $\begin{array}{l}0.009 \\
(0.02)\end{array}$ & $\begin{array}{l}0.150 \\
(0.29)\end{array}$ & $\begin{array}{l}0.112 \\
(0.21)\end{array}$ & $\begin{array}{l}0.780^{*} \\
(2.04)\end{array}$ & $\begin{array}{l}0.786^{*} \\
(2.09)\end{array}$ & $\begin{array}{l}0.755^{*} \\
(1.98)\end{array}$ & $\begin{array}{l}0.523 \\
(1.40)\end{array}$ & $\begin{array}{l}0.560 \\
(1.51)\end{array}$ & $\begin{array}{l}0.477 \\
(1.26)\end{array}$ \\
\hline $\mathrm{N}$ (children) & 953 & 966 & 947 & 953 & 966 & 947 & 953 & 966 & 947 \\
\hline $\mathrm{N}$ (cluster mothers) & 787 & 795 & 780 & 787 & 795 & 780 & 787 & 795 & 780 \\
\hline Pseudo- $R^{2}$ & 0.197 & 0.196 & 0.194 & 0.140 & 0.144 & 0.145 & 0.128 & 0.131 & 0.134 \\
\hline $\begin{array}{l}\text { Availability of day care } \\
\text { centers }\end{array}$ & $\checkmark$ & & & $\checkmark$ & & & $\checkmark$ & & \\
\hline Without civil servants & & $\checkmark$ & & & $\checkmark$ & & & $\checkmark$ & \\
\hline Without self-employed & & & $\checkmark$ & & & $\checkmark$ & & & $\checkmark$ \\
\hline
\end{tabular}

Level of significance: $+p<0.10, * p<0.05, * * p<0.01, * * * p<0.001$, t-statistics in parentheses Note: All models control for covariates listed in Table 3 plus quarter-year dummy variables.

Source: SOEP waves 2002-2012 (SOEP 2013, doi:10.5684/soep.v29), own calculations

not change our results. ${ }^{14}$ This result may presumably be explained by the fact that only very few parents use public day care in the first years of their child's life. Only two to three percent of all children attend day care in their first year of life (Statistisches Bundesamt 2013b), and thus, the availability of day care slots for children younger than one year may be of minor importance for our research question.

Secondly, we excluded civil servants from our sample. In our main specification, civil servants are included in the treatment group. However, civil servants might differ in when they return to work as they can take a much longer period of parental leave than all other employees. This specification produces similar results, indicating that results were not driven by an imprecise definition of treatment and control groups. Thirdly, an additional robustness check was performed by excluding self-employed mothers from the analysis. Despite being eligible for parental leave benefits, employment protection after childbirth does not apply to them. Again, the results remain unaffected.

\footnotetext{
${ }^{14}$ Missing data from the official statistics on publicly funded day care slots for children under three in 2004 and 2005 were imputed by using day care information from 2002 (data were provided by the Federal statistical office; Statistisches Bundesamt 2013a).
} 
Table 10: Robustness checks: The effect of parental leave on breastfeeding initiation and duration (multinominal logistic regression)

\begin{tabular}{|c|c|c|c|c|}
\hline & (1) & $(2)$ & (3) & (4) \\
\hline & \multicolumn{2}{|c|}{$\begin{array}{l}\text { No Breastfeeding at birth vs. } \\
\text { reference group: any breastfeeding up } \\
\text { to three months }\end{array}$} & \multicolumn{2}{|c|}{$\begin{array}{l}\text { No Breastfeeding at birth vs. } \\
\text { reference group: any breastfeeding up } \\
\text { to five months }\end{array}$} \\
\hline Reform & $\begin{array}{c}0.599 \\
(1.43)\end{array}$ & $\begin{array}{l}0.257 \\
(0.41)\end{array}$ & $\begin{array}{l}0.451 \\
(1.13)\end{array}$ & $\begin{array}{l}0.326 \\
(0.55)\end{array}$ \\
\hline Treatment & & $\begin{array}{l}-0.645 \\
(-1.55)\end{array}$ & & $\begin{array}{l}-0.578 \\
(-1.48)\end{array}$ \\
\hline \multirow[t]{2}{*}{ Reform x Treatment } & & $\begin{array}{l}0.480 \\
(0.79)\end{array}$ & & $\begin{array}{l}0.176 \\
(0.31)\end{array}$ \\
\hline & \multicolumn{2}{|c|}{$\begin{array}{l}\text { Breastfeeding at four months vs. } \\
\text { reference group: any breastfeeding up } \\
\text { to three months }\end{array}$} & \multicolumn{2}{|c|}{$\begin{array}{l}\text { Breastfeeding at six months vs. } \\
\text { reference group: any breastfeeding up } \\
\text { to five months }\end{array}$} \\
\hline Reform & $\begin{array}{c}0.719^{*} \\
(2.56)\end{array}$ & $\begin{array}{l}0.010 \\
-0.02\end{array}$ & $\begin{array}{c}0.619^{*} \\
(2.46)\end{array}$ & $\begin{array}{l}0.158 \\
(0.39)\end{array}$ \\
\hline Treatment & & $\begin{array}{l}-0.186 \\
(-0.59)\end{array}$ & & $\begin{array}{l}-0.093 \\
(-0.32)\end{array}$ \\
\hline Reform x Treatment & & $\begin{array}{c}0.914^{*} \\
(2.09)\end{array}$ & & $\begin{array}{l}0.572 \\
(1.41)\end{array}$ \\
\hline $\mathrm{N}$ (children) & 978 & 978 & 978 & 978 \\
\hline $\mathrm{N}$ (cluster mothers) & 802 & 802 & 802 & 802 \\
\hline Pseudo- $R^{2}$ & 0.157 & 0.163 & 0.142 & 0.146 \\
\hline
\end{tabular}

Level of significance: $+p<0.10, * p<0.05, * * p<0.01, * * * p<0.001$, t-statistics in parentheses Note: All models control for covariates listed in Table 3 plus quarter-year dummy variables.

Source: SOEP waves 2002-2012 (SOEP 2013, doi:10.5684/soep.v29), own calculations

Lastly, a multinominal logistic regression model was estimated to address the fact that our reference groups in the $\mathrm{DiD}$ estimations of breastfeeding at four and six months covers mothers who did not breast feed at all and thus who initiated breastfeeding with short breastfeeding durations (less than four months or six months, respectively). The outcome variables examined were (a) no breastfeeding at birth versus any breastfeeding up to three months, and breastfeeding at four months versus any breastfeeding up to three months (model specifications 1 and 2 in Table 10), and (b) no breastfeeding at birth versus any breastfeeding up to five months, and breastfeeding at six months versus any breastfeeding up to five months (model specifications 3 and 4 in Table 10). These model specifications also confirm our previous findings. 


\section{Discussion and Conclusions}

This study provides further insights into parental leave schemes and breastfeeding. It contributes to previous research in several ways. While the study by Baker \& Milligan (2008) examined both parental leave entitlement and cash benefits, they were not able to disentangle these two policy effects on breastfeeding. Although Huang \& Yang (2014) explored a parental leave scheme that introduced parental leave benefits but no job protection, it is not clear from the study how financial support for six weeks can affect breastfeeding duration up to nine months. In contrast to both of these studies, our study has been able to explore a single policy: namely, the introduction of a generous parental leave benefit in Germany.

We compared the breastfeeding behavior of German mothers before and after the 2007 parental leave benefit reform. We hypothesized that the parental leave reform should not affect breastfeeding initiation. Instead, we expected changes in breastfeeding duration. As expected, we did not find any effects of the new parental leave regulation on breastfeeding initiation. Breastfeeding for at least four months has increased significantly since the reform for mothers who were most likely to benefit from the new reform. However, we also did not find evidence of an increase in mothers who breastfeed their children for at least six months. The results are in line with the hypotheses and confirm two out of three hypotheses. In addition, a fictitious reform in 2006 had no effects on breastfeeding in the placebo regression, confirming that breastfeeding behavior does not differ in the absence of a policy intervention. Various model specifications show that our results were very robust when controlling for other potential mechanisms that might explain an increase in the proportion of mothers who breastfeed for at least four months.

The benefit reform did not impact all mothers in the same way. We find stronger effects on breastfeeding for East German mothers compared to West German mothers. This result might be due to different reasons for returning to the labor market earlier. Furthermore, East German mothers have generally higher employment rates than West German mothers (Pfau-Effinger \& Smidt 2011). Due to a lower household income in East Germany the necessity to return to the labor market is in principle higher for 
mothers in East Germany (Dressel, Cornelißen \& Wolf 2005). It could be that the increase in the benefit allowed East German mothers in particular to stay at home and breastfeed their child.

Nevertheless our study has some limitations. First, our data give us no information about whether or not the child was breastfed exclusively. But as long as there is no systematic variation due to our analyzed reform, this missing information should be of less concern. Second, employment is only one reason among others for the cessation of breastfeeding. Other reasons might be that mothers are exhausted due to breastfeeding or are experiencing health problems (Dulon, Kersting \& Schach 2001). However, controlling for health problems in the first three months after childbirth should at least partly account for this concern. Third, we cannot disentangle possible heterogeneity in the effects, given the sample size of our dataset. It would be interesting to know if the reform has a particularly strong effect on mothers with a higher or lower socio-economic status, as some campaigns to encourage breastfeeding focus on mothers with a lower socio-economic status. However, they have a higher probability to be in our control group, as there is no change in the benefit for low-income mothers who were not working before childbirth. The latter point is of great importance, as women with previous employment and/or high household income benefited most from the new parental leave reform. This is an essential aspect for the research on social and health inequalities in our control group. The group of mothers without pre-pregnancy employment and a low household income are not addressed by the reform and thus are not at risk of potential breastfeeding benefits, which in principle might come with the reform. This is of particular relevance, as these mothers are on average more vulnerable to social and health inequalities. Thus, policy makers and health care professionals have to be aware that those women need to be targeted differently to promote breastfeeding duration (Kohlhuber et al. 2008).

Our findings should be of interest to policy makers for multiple reasons. Given the goals of the German parental benefit reform, our results indicate that the reform was successful in the sense that parents with very young children were given the financial resources to interrupt work and take care of their very young child in the first year when the bonding between parents and children is of particular importance. With the new 
benefit, mothers are more likely to breastfeed for a longer period after their maternity leave ends. However, there is no change in the percentage of mothers who breastfeed for at least six months.

In respect to health policy, our results show how measures from other policy fields, such as family policy, can be effective in promoting the health of young children and their mothers at the same time. More concretely, parental leave benefits can be effective in improving the health both children and their mothers. However, more research is needed to determine whether these health effects actually occur and if they last over the medium and long term.

Moreover, it is important to point out that these benefits of the reform also have their costs. There are direct costs to taxpayers, who have to finance the increase in the parental leave benefit. Further, there might be additional opportunity costs to mothers who enter the labor market later. An evaluation of the efficiency of this change in the benefit would need to account fully for all benefits and costs.

Finally, from a family policy perspective, other policy measures might also be effective at alleviating the conflict mothers may experience between breastfeeding and working. Policy measures that allow mothers to manage both might also be useful. Employerprovided space and break time for the expression of breast milk or access to the child may also be helpful policy measures. Further research on this would help to better understand maternal coping strategies. 


\section{References}

Anderson, J. W., \& Johnstone, B. M., \& Remley, D. T. (1999): Breast-feeding and cognitive development: a meta-analysis. The American Journal of Clinical Nutrition, 70 No. 4, pp. 525-535

Baker, M., \& Milligan, K. (2008): Maternal employment, breastfeeding, and health: evidence from maternity leave mandates. Journal of Health Economics, 27 No. 4, pp. 871-87

Baker, M., \& Milligan, K. (2010): Evidence from Maternity Leave Expansions of the Impact of Maternal Care on Early Child Development. Journal of Human Resources, 45 No. 1, pp. 1-32, 547ID Times Cited:7 Cited References Count:28

Beivers, A., \& Spangenberg, M. (2008): Ländliche Krankenhausversorgung im Fokus der Raumordnung. Informationen zur Raumentwicklung, 1/2.2008, pp. 91-99

Belfield, C. R., \& Kelly, I. R. (2012): The Benefits of Breast Feeding across the Early Years of Childhood. Journal of Human Capital, 6 No. 3, pp. 251-277

Beral, V. et al. (2002): Breast cancer and breastfeeding: collaborative reanalysis of individual data from 47 epidemiological studies in 30 countries, including 50.302 women with breast cancer and 96.973 women without the disease. The Lancet, 360 No. 9328, pp. 187-195

Berger, L. M., \& Hill, J., \& Waldfogel, J. (2005): Maternity leave, early maternal employment and child health and development in the US. Economic Journal, 115 No. 501, pp. F29-F47

Bertini, G. et al. (2003): Maternal Education and the Incidence and Duration of Breast Feeding: A Prospective Study. Journal of Pediatric Gastroenterology and Nutrition, 37 No. 4, pp. 447-452

BFHI (2013): Jahresbericht 2013. 〈URL: http://www.babyfreundlich.org/fileadmin/user upload/download/verein_und_vorstand/Baby_Jahresbericht_2013_Web2_300dpi.pdf $\rangle$, accessed 29 November 2013

BFHI (2014): WHO/UNICEF-Initiative Babyfreundliches Krankenhaus (BFHI). 〈URL: http://www . babyfreundlich.org $\rangle$, accessed 21 January 2014

Bick, D. E., \& MacArthur, C., \& Lancashire, R. J. (1998): What influences the uptake and early cessation of breast feeding? Midwifery, 14 No. 4, pp. 242-247

BMFSFJ (2008): Evaluation des Gesetzes zum Elterngeld und zur Elternzeit - Endbericht 2008. Bundesministerium für Familie, Senioren, Frauen und Jugend - Technical report

Borra, C., \& Iacovou, M., \& Sevilla, A. (2012): The effect of breastfeeding on children's cognitive and noncognitive development. Labour Economics, 19 No. 4, pp. 496-515

Bujard, M. (2013): Elterngeld und Elternzeit in Deutschland: Ziele, Diskurse und Wirkungen. Zeitschrift für Familienforschung, 25 No. 3, pp. 123-131

Bujard, M., \& Passet, J. (2013): Wirkungen des Elterngelds auf Einkommen und Fertilität. Zeitschrift für Familienforschung, 25 No. 3, pp. 212-237

Bundesinstitut für Risikobewertung (2004): Empfehlungen zur Stilldauer. Bundesgesundheitsblatt Gesundheitsforschung - Gesundheitsschutz, 47 No. 9, p. 908

Carneiro, P., \& Loken, K. V., \& Salvanes, K. G. (2011): A Flying Start? Maternity Leave Benefits and Long Run Outcomes of Children. Institute for the Study of Labor (IZA) - Technical report

Chatterji, P., \& Frick, K. (2005): Does Returning to Work After Childbirth Affect Breastfeeding Practices? Review of Economics of the Household, 3 No. 3, pp. 315-335

Colen, C. G., \& Ramey, D. M. (2014): Is breast truly best? Estimating the effects of breastfeeding on long-term child health and wellbeing in the United States using sibling comparisons. Social Science \& Medicine, 109 No. May 2014, pp. 55-65, ISSN 0277-9536 
Del Bono, E., \& Rabe, B. (2012): Breastfeeding and child cognitive outcomes: evidence from a hospitalbased breastfeeding support policy. Institute for Social and Economic Research - Technical report

Dennis, C.-L. (2002): Breastfeeding Initiation and Duration: A 1990-2000 Literature Review. Journal of Obstetric, Gynecologic, \& Neonatal Nursing, 31 No. 1, pp. 12-32

Destatis (2011): Öffentliche Sozialleistungen. Statistik zum Elterngeld. Gemeldete beendete Leistungsbezüge. Jahr 2010. Statistisches Bundesamt - Technical report

Deutscher Bundestag (2006): Entwurf eines Gesetzes zur Einführung des Elterngeldes. BundestagsDrucksache 16/1889, 20 June 2006

Drasch, K. (2013): Educational Attainment and Family-Related Employment Interruptions in Germany: Do Changing Institutional Settings Matter? European Sociological Review, 29 No. 5, pp. $981-995$

Dressel, C., \& Cornelißen, W., \& Wolf, K.; Cornelißen, W. (Eds.) (2005): Vereinbarkeit von Familie und Beruf. Im Auftrag des Bundesministeriums für Familie, Senioren, Frauen und Jugend (BMFSFJ), Berlin, pp. 278-356

Dulon, M., \& Kersting, M., \& Schach, S. (2001): Duration of breastfeeding and associated factors in Western and Eastern Germany. Acta Pcediatrica, 90 No. 8, pp. 931-935

Dustmann, C., \& Schönberg, U. (2012): Expansions in Maternity Leave Coverage and Children's Long-Term Outcomes. American Economic Journal: Applied Economics, 4 No. 3, pp. 190-224

Fein, S. B., \& Roe, B. (1998): The effect of work status on initiation and duration of breast-feeding. American Journal of Public Health, 88 No. 7, pp. 1042-1046

Flacking, R., \& Dykes, F., \& Ewald, U. (2010): The influence of fathers' socioeconomic status and paternity leave on breastfeeding duration: A population-based cohort study. Scandinavian Journal of Public Health, 38 No. 4, pp. 337-343

GBE (2012): Entbindungen in Krankenhäusern. Gliederungsmerkmale: Jahre, Region, Art der Entbindung., basierend auf Krankenhausstatistik - Grunddaten des Statistischen Bundesamtes 〈URL: www.gbe-bund.de〉, accessed 24 October 2012

Gielen, A. C. et al. (1991): Maternal Employment During the Early Postpartum Period: Effects on Initiation and Continuation of Breast-feeding. Pediatrics, 87 No. 3, pp. 298-305

Grjibovski, A. M. et al. (2005): Socio-demographic determinants of initiation and duration of breastfeeding in northwest Russia. Acta Pcediatrica, 94 No. 5, pp. 588-594

Guendelman, S. et al. (2009): Juggling Work and Breastfeeding: Effects of Maternity Leave and Occupational Characteristics. Pediatrics, 123 No. 1, pp. E38-E46

Hajian-Tilaki, K. O. (2005): Factors associated with the pattern of breastfeeding in the north of Iran. Annals of Human Biology, 32 No. 6, pp. 702-713

Heck, K. E. et al. (2006): Socioeconomic Status and Breastfeeding Initiation Among California Mothers. Public Health Reports, 121 No. 1, pp. 51-59

Huang, R., \& Yang, M. (2014): Paid Maternity Leave and Breastfeeding Practice Before and After California's Implementation of the Nation's First Paid Family Leave Program. Economics 86 Human Biology in press

Hyde, M. J. et al. (2012): The health implications of birth by Caesarean section. Biological Reviews, 87 No. 1, pp. 229-243

Kersting, M., \& Dulon, M. (2002): Fakten zum Stillen in Deutschland. Monatsschrift Kinderheilkunde, 150 No. 10 , pp. $1196-1201$

Kimbro, R. (2006): On-the-Job Moms: Work and Breastfeeding Initiation and Duration for a Sample of Low-Income Women. Maternal and Child Health Journal, 10 No. 1, pp. 19-26 
Kluve, J., \& Schmitz, S. (2014): Social Norms and Mothers' Labor Market Attachment: The MediumRun Effects of Parental Benefits. Institute for the Study of Labor (IZA) - Technical report, IZA Discussion Papers

Kluve, J., \& Tamm, M. (2013): Parental leave regulations, mothers' labor force attachment and fathers' childcare involvement: evidence from a natural experiment. Journal of Population Economics, 26 No. 3, pp. 983-1005

Kobayashi, M., \& Usui, E. (2014): Breastfeeding practices and parental employment in Japan. Review of Economics of the Household, pp. 1-18

Kohlhuber, M. et al. (2008): Breastfeeding rates and duration in Germany: a Bavarian cohort study. British Journal of Nutrition, 99 No. 05, pp. 1127-1132

Koletzko, B. et al. (2013): Säuglingsernährung und Ernährung der stillenden Mutter. Monatsschrift Kinderheilkunde, 161, pp. 237-246

Kottwitz, A., \& Spiess, K. C., \& Wagner, G. G.; Villa, P.-I., \& Moebius, S., \& Thiessen, B., editors (2011): Die Geburt im Kontext der Zeit kurz davor und danach - Eine repräsentative empirische Beschreibung der Situation in Deutschland auf der Basis des Sozio-oekonomischen Panels (SOEP). Frankfurt am Main: Campus Verlag, pp. 129-154

Kurinij, N. et al. (1989): Does maternal employment affect breast-feeding? American Journal of Public Health, 79 No. 9, pp. 1247-1250

Lalive, R., \& Zweimuller, J. (2009): How Does Parental Leave Affect Fertility and Return to Work? Evidence from Two Natural Experiments. Quarterly Journal of Economics, 124 No. 3, pp. 13631402

Lange, C., \& Schenk, L., \& Bergmann, R. (2007): Verbreitung, Dauer und zeitlicher Trend des Stillens in Deutschland. Bundesgesundheitsblatt - Gesundheitsforschung - Gesundheitsschutz, 50 No. 5 , pp. $624-633$

Lindberg, L. D. (1996): Women's Decisions about Breastfeeding and Maternal Employment. Journal of Marriage and Family, 58 No. 1, pp. 239-251

Liu, Q., \& Skans Oskar, N. (2010): The Duration of Paid Parental Leave and Children's Scholastic Performance. The B.E. Journal of Economic Analysis \& Policy, 10 No. 1, pp. 1-35

McCrory, C., \& Layte, R. (2012): Breastfeeding and risk of overweight and obesity at nine-years of age. Social Science \&5 Medicine, 75 No. 2, pp. 323-330

McLafferty, S. L. (2003): GIS and health care. Annual Review of Public Health, 24 No. 1, pp. 25-42

Noble, S., \& Team, T. A. S. (2001): Maternal employment and the initiation of breastfeeding. Acta Padiatrica, 90 No. 4, pp. 423-428

OECD (2014): OECD Family database. LMF1.2 Maternal employment. 〈URL: http://www.oecd. org/els/family/LMF1_2_Maternal_Employment_July2013.xls〉, accessed 14 April 2014

Ogbuanu, C. et al. (2011): The Effect of Maternity Leave Length and Time of Return to Work on Breastfeeding. Pediatrics, 127 No. 6, pp. E1414-E1427

Ondrich, J. et al. (2003): The Liberalization of Maternity Leave Policy and the Return to Work after Childbirth in Germany. Review of Economics of the Household, 1 No. 1-2, pp. 77-110

Pfau-Effinger, B., \& Smidt, M. (2011): Differences in women's employment patterns and family policies: eastern and western Germany. Community, Work $\&$ Family, 14 No. 2, pp. 217-232

Prior, E. et al. (2012): Breastfeeding after cesarean delivery: a systematic review and meta-analysis of world literature. The American Journal of Clinical Nutrition, 95 No. 5, pp. 1113-1135

Puhani, P. A. (2012): The treatment effect, the cross difference, and the interaction term in nonlinear "difference-in-differences" models. Economics Letters, 115 No. 1, pp. 85-87 
Rasmussen, A. W. (2010): Increasing the length of parents' birth-related leave: The effect on children's long-term educational outcomes. Labour Economics, 17 No. 1, pp. 91-100

Roe, B. et al. (1999): Is There Competition between Breast-Feeding and Maternal Employment? Demography, 36 No. 2, pp. 157-171

Rogers, W. H. (1993): Regression standard errors in clustered samples. Stata Technical Bulletin (Reprinted in Stata Technical Bulletin Reprints, Vol. 3, 88-94), 13, pp. 19-23

Rubin, D. (2013): Stillen in Deutschland. Ernährung im Fokus, 2013 No. 7-8, pp. 200-205

Ruhm, C. J. (2000): Parental leave and child health. Journal of Health Economics, 19 No. 6, pp. 931960

Schönberg, U., \& Ludsteck, J. (2007): Maternity Leave Legislation, Female Labor Supply, and the Family Wage Gap. Institute for the Study of Labor (IZA) - Technical report, IZA Discussion Papers

Smith, J., \& Ellwood, M. (2011): Feeding Patterns and Emotional Care in Breastfed Infants. Social Indicators Research, 101 No. 2, pp. 227-231

SOEP (2013): Socio-Economic Panel (SOEP), data for years 1984-2012, version 29.

Spiess, C. K. (2011): Ever-Increasing Opportunities for Child-Related Research with the German Socio-Economic Panel (SOEP) Study. LIFE Research School Newsletter. Max Planck Institute for Human Development, 5 No. 1, pp. 2-5

Spiess, C. K., \& Wrohlich, K. (2008): The Parental Leave Benefit Reform in Germany: Costs and Labour Market Outcomes of Moving towards the Nordic Model. Population Research and Policy Review, 27 No. 5, pp. 575-591

Statistisches Bundesamt (2013a): Regionaldatenbank. Wiesbaden 〈URL: www.regionalstatistik. de $\rangle$, accessed 15 October 2013

Statistisches Bundesamt (2013b): Statistik der Kinder- und Jugendhilfe Teil III. Kinder in Tageseinrichtungen nach Ländern, Altersgruppen und Besuchsquoten am 1.3.2013. Wiesbaden

Tanaka, S. (2005): Parental leave and child health across OECD countries. The Economic Journal, 115 No. 501, pp. F7-F28

Thyrian, J. R. et al. (2010): Changing maternity leave policy: Short-term effects on fertility rates and demographic variables in Germany. Social Science \& Medicine, 71 No. 4, pp. 672-676

Visness, C. M., \& Kennedy, K. I. (1997): Maternal employment and breast-feeding: findings from the 1988 National Maternal and Infant Health Survey. American Journal of Public Health, 87 No. 6, pp. 945-950

Wagner, G. G., \& Frick, J. R., \& Schupp, J. (2007): The German Socio-Economic Panel Study (SOEP) - Scope, Evolution and Enhancements. Schmollers Jahrbuch, 127, pp. 139-169

Waldfogel, J., \& Han, W.-J., \& Brooks-Gunn, J. (2002): The Effects of Early Maternal Employment on Child Cognitive Development. Demography, 39 No. 2, pp. 369-392

World Health Organization and UNICEF (2003): Global strategy for infant and young child feeding. World Health Organization - Technical report/URL: www . who.int/nutrition/topics/ global_strategy/en/index.html, , accessed 15 January 2014

World Health Organization and UNICEF (2009): Baby-friendly hospital initiative : revised, updated and expanded for integrated care. Section 1, Background and implementation. /URL: http://www.who.int/nutrition/publications/infantfeeding/bfhi_ trainingcourse_s1/en/index.html $\rangle$, accessed 20 January 2014 
Wrohlich, K. et al. (2012a): Elterngeld Monitor: Endbericht; Forschungsprojekt im Auftrag des Bundesministeriums für Familie, Senioren, Frauen und Jugend. DIW Berlin - Politikberatung kompakt 〈URL: http://nbn-resolving.de/urn:nbn:de:0084-diwkompakt_2012-0611), accessed 07 August 2013

Wrohlich, K. etal. (2012b): Studie: Elterngeld-Monitor. Kurzfassung. 〈URL: http://www.bmfsfj.de/RedaktionBMFSFJ/Broschuerenstelle/Pdf-Anlagen/ Elterngeld-Monitor-Studie-Kurzfassung, property=pdf , bereich=bmfsf $j$, sprache= de, $r w b=$ true.pdf $\rangle$, accessed 01 August 2013 
A. Appendix 
Table A1: Predicted Probabilities of DiD estimates on breastfeeding initiation and duration; Sensitivity analyses

\begin{tabular}{|c|c|c|c|}
\hline & Breastfeeding at birth & $\begin{array}{c}\text { Breastfeeding at four } \\
\text { months }\end{array}$ & $\begin{array}{c}\text { Breastfeeding at six } \\
\text { months }\end{array}$ \\
\hline \multicolumn{4}{|c|}{ Model 1: East German mother, mother's age at birth of child: 25 , first child } \\
\hline Before\#Control & $\begin{array}{c}0.931^{* * *} \\
(21.00)\end{array}$ & $\begin{array}{l}0.527^{* * * *} \\
(4.97)\end{array}$ & $\begin{array}{l}0.397 * * * \\
(4.10)\end{array}$ \\
\hline Before\#Treatment & $\begin{array}{c}0.956^{* * * *} \\
(34.81)\end{array}$ & $\begin{array}{l}0.536^{* * *} \\
(5.64)\end{array}$ & $\begin{array}{l}0.413^{* * *} \\
(4.74)\end{array}$ \\
\hline After\#Control & $\begin{array}{c}0.918^{* * *} \\
(23.80)\end{array}$ & $\begin{array}{l}0.503^{* * *} \\
(6.52)\end{array}$ & $\begin{array}{l}0.408^{* * *} \\
(5.50)\end{array}$ \\
\hline After\#Treatment & $\begin{array}{c}0.953^{* * *} \\
(41.06)\end{array}$ & $\begin{array}{c}0.667^{* * * *} \\
(10.44)\end{array}$ & $\begin{array}{c}0.535^{* * *} \\
(7.93)\end{array}$ \\
\hline Control: Diff. After - Before & $\begin{array}{l}-0.013 \\
(-0.39)\end{array}$ & $\begin{array}{l}-0.024 \\
(-0.29)\end{array}$ & $\begin{array}{l}0.011 \\
(0.14)\end{array}$ \\
\hline Treatment: Diff. After - Before & $\begin{array}{l}-0.003 \\
(-0.23)\end{array}$ & $\begin{array}{l}0.132^{*} \\
(2.43)\end{array}$ & $\begin{array}{c}0.121^{*} \\
(2.55)\end{array}$ \\
\hline DiD & $\begin{array}{l}0.009 \\
(0.30)\end{array}$ & $\begin{array}{c}0.156^{*} \\
(1.99)\end{array}$ & $\begin{array}{l}0.111 \\
(1.45)\end{array}$ \\
\hline \multicolumn{4}{|c|}{ Model 2: West German mother, mother's age at birth of child: 30 , first child } \\
\hline Before\#Control & $\begin{array}{c}0.866^{* * *} \\
(22.26)\end{array}$ & $\begin{array}{c}0.643^{* * *} \\
(11.78)\end{array}$ & $\begin{array}{c}0.572^{* * *} \\
(10.25)\end{array}$ \\
\hline Before\#Treatment & $\begin{array}{c}0.912^{* * * *} \\
(53.79)\end{array}$ & $\begin{array}{c}0.651^{* * * *} \\
(21.73)\end{array}$ & $\begin{array}{c}0.588^{* * * *} \\
(19.10)\end{array}$ \\
\hline After \#Control & $\begin{array}{c}0.845^{* * * *} \\
(13.15)\end{array}$ & $\begin{array}{l}0.620^{* * * *} \\
(8.53)\end{array}$ & $\begin{array}{l}0.584^{* * * *} \\
(8.06)\end{array}$ \\
\hline After\#Treatment & $\begin{array}{c}0.905^{* * *} \\
(28.58)\end{array}$ & $\begin{array}{c}0.767^{* * * *} \\
(19.82)\end{array}$ & $\begin{array}{c}0.701^{* * *} \\
(16.70)\end{array}$ \\
\hline Control: Diff. After - Before & $\begin{array}{l}-0.022 \\
(-0.36)\end{array}$ & $\begin{array}{l}-0.023 \\
(-0.29)\end{array}$ & $\begin{array}{l}0.011 \\
(0.14)\end{array}$ \\
\hline Treat: Diff. After - Before & $\begin{array}{l}-0.006 \\
(-0.22)\end{array}$ & $\begin{array}{c}0.115^{* *} \\
(2.74)\end{array}$ & $\begin{array}{c}0.113^{*} \\
(2.57)\end{array}$ \\
\hline DiD & $\begin{array}{l}0.015 \\
(0.28)\end{array}$ & $\begin{array}{c}0.138+ \\
(1.85)\end{array}$ & $\begin{array}{l}0.102 \\
(1.33)\end{array}$ \\
\hline \multicolumn{4}{|c|}{ Model 3: West German mother, mother's age at birth of child: 25 , first child } \\
\hline Before\#Control & $\begin{array}{c}0.875^{* * *} \\
(24.41)\end{array}$ & $\begin{array}{c}0.616^{* * *} \\
(11.25)\end{array}$ & $\begin{array}{c}0.550^{* * *} \\
(9.89)\end{array}$ \\
\hline Before\#Treatment & $\begin{array}{c}0.918^{* * *} \\
(50.55)\end{array}$ & $\begin{array}{c}0.624^{* * *} * \\
(17.68)\end{array}$ & $\begin{array}{c}0.566^{* * *} \\
(15.74)\end{array}$ \\
\hline After\#Control & $\begin{array}{c}0.854^{* * *} \\
(14.17)\end{array}$ & $\begin{array}{c}0.593^{* * *} * \\
(7.92)\end{array}$ & $\begin{array}{c}0.562^{* * *} \\
(7.66)\end{array}$ \\
\hline After\#Treatment & $\begin{array}{c}0.912^{* * *} \\
(30.23)\end{array}$ & $\begin{array}{c}0.744^{* * *} \\
(17.25)\end{array}$ & $\begin{array}{c}0.682^{* * *} \\
(14.79)\end{array}$ \\
\hline Control: Diff. After - Before & $\begin{array}{l}-0.021 \\
(-0.36)\end{array}$ & $\begin{array}{l}-0.023 \\
(-0.29)\end{array}$ & $\begin{array}{l}0.011 \\
(0.14)\end{array}$ \\
\hline Treatment: Diff. After - Before & $\begin{array}{l}-0.006 \\
(-0.22)\end{array}$ & $\begin{array}{c}0.120^{* *} \\
(2.72)\end{array}$ & $\begin{array}{c}0.115^{*} \\
(2.56)\end{array}$ \\
\hline DiD & $\begin{array}{l}0.015 \\
(0.28)\end{array}$ & $\begin{array}{c}0.143+ \\
(1.87)\end{array}$ & $\begin{array}{l}0.104 \\
(1.34)\end{array}$ \\
\hline
\end{tabular}

continued on next page 
Table A1: continued

\begin{tabular}{|c|c|c|c|}
\hline & Breastfeeding at birth & $\begin{array}{c}\text { Breastfeeding at four } \\
\text { months }\end{array}$ & $\begin{array}{c}\text { Breastfeeding at six } \\
\text { months }\end{array}$ \\
\hline \multicolumn{4}{|c|}{ Model 4: East German mother, mother's age at birth of child: 30 , not the first child } \\
\hline Before\#Control & $\begin{array}{c}0.901^{* * *} \\
(15.67)\end{array}$ & $\begin{array}{l}0.548^{* * *} \\
(5.42)\end{array}$ & $\begin{array}{c}0.397^{* * *} \\
(4.25)\end{array}$ \\
\hline Before\#Treatment & $\begin{array}{c}0.936^{* * *} \\
(24.80)\end{array}$ & $\begin{array}{c}0.557^{* * *} \\
(6.10)\end{array}$ & $\begin{array}{c}0.412^{* * *} \\
(4.90)\end{array}$ \\
\hline After\#Control & $\begin{array}{c}0.884^{* * *} \\
(19.26)\end{array}$ & $\begin{array}{c}0.524^{* * *} \\
(7.31)\end{array}$ & $\begin{array}{c}0.408^{* * *} \\
(5.97)\end{array}$ \\
\hline After\#Treatment & $\begin{array}{c}0.932^{* * *} \\
(30.03)\end{array}$ & $\begin{array}{c}0.686^{* * *} \\
(11.83)\end{array}$ & $\begin{array}{c}0.534^{* * *} \\
(8.58)\end{array}$ \\
\hline Control: Diff. After - Before & $\begin{array}{l}-0.017 \\
(-0.39)\end{array}$ & $\begin{array}{l}-0.024 \\
(-0.29)\end{array}$ & $\begin{array}{l}0.011 \\
(0.14)\end{array}$ \\
\hline Treatment: Diff. After - Before & $\begin{array}{l}-0.005 \\
(-0.23)\end{array}$ & $\begin{array}{l}0.129^{*} \\
(2.39)\end{array}$ & $\begin{array}{l}0.121^{*} \\
(2.56)\end{array}$ \\
\hline $\mathrm{DiD}$ & $\begin{array}{l}0.012 \\
(0.30)\end{array}$ & $\begin{array}{l}0.153^{*} \\
(1.97)\end{array}$ & $\begin{array}{l}0.111 \\
(1.45)\end{array}$ \\
\hline \multicolumn{4}{|c|}{ Model 5: East-German mother, mother's age at birth of child: 25, not the first child } \\
\hline Before\#Control & $\begin{array}{c}0.908^{* * *} \\
(16.45)\end{array}$ & $\begin{array}{c}0.519^{* * *} \\
(5.10)\end{array}$ & $\begin{array}{c}0.376^{* * *} \\
(4.06)\end{array}$ \\
\hline Before\#Treatment & $\begin{array}{c}0.941^{* * *} \\
(25.48)\end{array}$ & $\begin{array}{c}0.528^{* * *} \\
(5.58)\end{array}$ & $\begin{array}{c}0.391^{* * *} \\
(4.55)\end{array}$ \\
\hline After\#Control & $\begin{array}{c}0.891^{* * *} \\
(20.01)\end{array}$ & $\begin{array}{c}0.495^{* * *} \\
(6.73)\end{array}$ & $\begin{array}{c}0.386^{* * *} \\
(5.61)\end{array}$ \\
\hline After\#Treatment & $\begin{array}{c}0.936^{* * *} \\
(30.70)\end{array}$ & $\begin{array}{c}0.660^{* * *} \\
(10.39)\end{array}$ & $\begin{array}{l}0.512^{* * *} \\
(7.64)\end{array}$ \\
\hline Control: Diff. After - Before & $\begin{array}{l}-0.016 \\
(-0.39)\end{array}$ & $\begin{array}{l}-0.024 \\
(-0.29)\end{array}$ & $\begin{array}{l}0.011 \\
(0.14)\end{array}$ \\
\hline Treatment: Diff. After - Before & $\begin{array}{l}-0.004 \\
(-0.23)\end{array}$ & $\begin{array}{l}0.132^{*} \\
(2.44)\end{array}$ & $\begin{array}{c}0.121^{* *} \\
(2.59)\end{array}$ \\
\hline $\mathrm{DiD}$ & $\begin{array}{l}0.012 \\
(0.30)\end{array}$ & $\begin{array}{l}0.156^{*} \\
(1.99)\end{array}$ & $\begin{array}{l}0.110 \\
(1.46)\end{array}$ \\
\hline \multicolumn{4}{|c|}{ Model 6: West German mother, mother's age at birth of child: 30 , not the first child } \\
\hline Before\#Control & $\begin{array}{c}0.828^{* * * *} \\
(19.98)\end{array}$ & $\begin{array}{c}0.636^{* * *} \\
(12.35)\end{array}$ & $\begin{array}{c}0.550^{* * *} \\
(10.08)\end{array}$ \\
\hline Before\#Treatment & $\begin{array}{c}0.884^{* * *} \\
(36.41)\end{array}$ & $\begin{array}{c}0.644^{* * *} \\
(18.35)\end{array}$ & $\begin{array}{c}0.566^{* * *} \\
(15.37)\end{array}$ \\
\hline After\#Control & $\begin{array}{c}0.802^{* * *} \\
(11.61)\end{array}$ & $\begin{array}{c}0.613^{* * *} \\
(8.43)\end{array}$ & $\begin{array}{c}0.561^{* * *} \\
(7.87)\end{array}$ \\
\hline After\#Treatment & $\begin{array}{c}0.876^{* * *} \\
(22.48)\end{array}$ & $\begin{array}{c}0.761^{* * *} \\
(18.38)\end{array}$ & $\begin{array}{c}0.681^{* * *} \\
(14.93)\end{array}$ \\
\hline Control: Diff. After - Before & $\begin{array}{l}-0.026 \\
(-0.36)\end{array}$ & $\begin{array}{l}-0.023 \\
(-0.29)\end{array}$ & $\begin{array}{l}0.011 \\
(0.14)\end{array}$ \\
\hline Treatment: Diff. After - Before & $\begin{array}{l}-0.008 \\
(-0.22)\end{array}$ & $\begin{array}{c}0.117^{* *} \\
(2.72)\end{array}$ & $\begin{array}{l}0.116^{*} \\
(2.55)\end{array}$ \\
\hline $\mathrm{DiD}$ & $\begin{array}{l}0.018 \\
(0.28)\end{array}$ & $\begin{array}{c}0.139+ \\
(1.84)\end{array}$ & $\begin{array}{l}0.104 \\
(1.34)\end{array}$ \\
\hline
\end{tabular}

continued on next page 
Table A1: continued

\begin{tabular}{|c|c|c|c|}
\hline & Breastfeeding at birth & $\begin{array}{c}\text { Breastfeeding at four } \\
\text { months }\end{array}$ & $\begin{array}{c}\text { Breastfeeding at six } \\
\text { months }\end{array}$ \\
\hline \multicolumn{4}{|c|}{ Model 7 West-German mother, mother's age at birth of child: 25 , not the first child } \\
\hline Before\#Control & $\begin{array}{c}0.838^{* * *} \\
(19.96)\end{array}$ & $\begin{array}{c}0.609^{* * *} \\
(10.84)\end{array}$ & $\begin{array}{c}0.527^{* * *} \\
(8.98)\end{array}$ \\
\hline Before\#Treatment & $\begin{array}{c}0.891^{* * *} \\
(31.12)\end{array}$ & $\begin{array}{c}0.617^{* * *} \\
(13.47)\end{array}$ & $\begin{array}{c}0.543^{* * *} \\
(11.53)\end{array}$ \\
\hline After\#Control & $\begin{array}{c}0.813^{* * *} \\
(11.98)\end{array}$ & $\begin{array}{c}0.585^{* * *} \\
(7.49)\end{array}$ & $\begin{array}{c}0.539^{* * *} \\
(7.14)\end{array}$ \\
\hline After\#Treatment & $\begin{array}{c}0.883^{* * *} \\
(22.20)\end{array}$ & $\begin{array}{c}0.738^{* * *} \\
(14.90)\end{array}$ & $\begin{array}{c}0.661^{* * *} \\
(12.28)\end{array}$ \\
\hline Control: Diff. After - Before & $\begin{array}{l}-0.025 \\
(-0.36)\end{array}$ & $\begin{array}{l}-0.023 \\
(-0.29)\end{array}$ & $\begin{array}{l}0.011 \\
(0.14)\end{array}$ \\
\hline Treatment: Diff. After - Before & $\begin{array}{l}-0.007 \\
(-0.22)\end{array}$ & $\begin{array}{c}0.121^{* *} \\
(2.70)\end{array}$ & $\begin{array}{l}0.118^{*} \\
(2.54)\end{array}$ \\
\hline $\mathrm{DiD}$ & $\begin{array}{l}0.017 \\
(0.28)\end{array}$ & $\begin{array}{c}0.145+ \\
(1.86)\end{array}$ & $\begin{array}{l}0.106 \\
(1.36)\end{array}$ \\
\hline $\mathrm{N}$ & 978 & 978 & 978 \\
\hline
\end{tabular}

Level of significance: $+p<0.10, * p<0.05, * * p<0.01, * * * p<0.001$, t-statistics in parentheses Note: Predicted probabilities base on a logistic regression model by holding covariates fixed at following values: All models are calculated for mothers with childbirth at term who were in good physical health during the first three months after birth.

Source: SOEP waves 2002-2012 (SOEP 2013, doi:10.5684/soep.v29), own calculations 